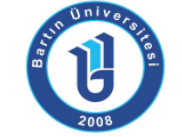

ISSN: 1308-7177

\title{
Öğretmen Adaylarının Benlik Saygıları ve Mesleki Benlik Saygılarının Çeşitli Değişkenler Açısından İncelenmesi
}

Havise GÜLEÇ, Doç. Dr., Çanakkale On Sekiz Mart Üniversitesi Eğitim Fakültesi, havisegulec@yahoo.com

Ceylan ÖZBEK AYAZ, Öğr. Gör., Namık Kemal Üniversitesi Sağlık Hizmetleri Meslek Yüksekokulu, ceylanayaz@nku.edu.tr

Öz: Bu çalışmanın amacı öğretmen adaylarının benlik saygıları ve mesleki benlik saygılarının çeşitli değişkenler açısından farkılık gösterip göstermediklerini belirlemektir. Çalışma grubu 420 öğretmen adayından oluşmaktadır. Araştırmada veriler "Rosenberg Benlik Saygısı Ölçeği”, "Arıcak (1999) Mesleki Benlik Saygısı Ölçeği" ve Kişisel Bilgi Formu kullanılarak toplanmıştır. Araştırma sonuçlarına göre Fen bilgisi eğitimi anabilim dalında okuyan öğrencilerin benlik saygılarının İngiliz dili eğitimi anabilim dalında okuyan öğrencilere nazaran daha yüksek olduğu; cinsiyet, yaş, sınıf düzeyi, mezun olunan lise türü, yükseköğretimi tercih sırası ve ailede öğretmen olup olmama durumu değişkenlerinin benlik saygısı üzerinde anlamlı fark yaratmadığı belirlenmiştir. Adayların mesleki benlik saygısı düzeylerinin anabilim dalı, yaş, sınıf düzeyi, mezun oldukları lise türü ve ailede öğretmen olup olmama değişkenlerinden etkilenmediği; ancak cinsiyet ve yükseköğretimdeki tercih sırası değişkenlerine göre anlamlı değişim gösterdiği tespit edilmiştir.

Anahtar Kelimeler: yükseköğretim, öğretmen adayı, öğretmenlik mesleği, benlik saygıSı, mesleki benlik saygısı

\section{Study of Self Esteem and Professional Self Esteem of Teacher Candidates in terms of Several Variables}

\begin{abstract}
The goal of this study is to examine whether self esteem and professional self esteem of teacher candidates vary according to several variables. The study data was collected with "Rosenberg Self Esteem Scale", "Arıcak (1999) Professional Self Esteem Scale" and Personal Data Form. Study findings show that self esteem of science students is higher than English literature students and self esteem is not related to gender, age, grade, type of graduted high school, higher education preference order and presence of a teacher in the family. Findings also showed that professional self esteem of teacher candidates is not related to school department, age, grade, type of graduated high school and presence of a teacher in the family; however there is a significant relationship between professional self esteem and gender and higher education preference order.
\end{abstract}

Key Words: higher education, teacher candidate, teaching profession, self esteem, professional self esteem 


\section{GiRiş}

Kişilik, bireyi başkalarından ayıran, doğuştan getirilen ve sonradan kazanılan özelliklerin bütünüdür. Kişilik, bireyin zihinsel, duygusal, sosyal ve fiziksel özelliklerinin süreklilik gösteren yönlerini içerir. Kişilik gelişiminin amacı olgun ve dengeli bir benlik geliştirmektir (Özdemir, Güzel Özdemir, Kadak ve Nasıroğlu, 2012, s. 566).

\subsection{Benlik}

Benlik kavramı kişinin kendi kendisini bilinçli olarak nasıl tanımladığını ve değerlendirdiğini gösteren, insanların kişi olarak ne kadar değerli oldukları ve kendileri hakkındaki değerlerini ifade eden bir kavramdır (Kong, Ding ve Zhao, 2015, s. 479; Pasha ve Munaf, 2013, s. 999; Thomaes, Poorthuis ve Nelemans, 2011). Bu değerler olumlu ya da olumsuz olabilmektedir (Adler ve Stewart, 2004; Cüceloğlu, 2006, s. 428) Benlik saygısının olumlu olması kişinin yaşam doyumuna katkıda bulunmaktadır (Kong, Ding ve Zhao, 2015, s. 479; Öztaş, 2009, s. 321). Deniz'in (2006) üniversite öğrencileriyle yaptığı çalışmada öğrencilerin benlik saygısının yaşam doyumu ile olumlu ilişki içinde olduğunu belirtmesi bu kanıyı desteklemektedir.

Rosenberg benlik saygısını kişinin kendisini olduğu gibi kabul etmesi, onaylaması ve değer vermesi olarak tanımlamaktadır (Adler ve Stewart, 2004; Negovan ve Bagana, 2011, s. 1325). Benlik saygısı yüksek olan kişiler kendine güvenli, etkili iletişim kurabilen ve sağlam ilişkiler geliştirebilen kişiler oldukları için toplumsal anlamda da uyumludur (Gül, 2013, s. 195). Bu kişiler elde etmek istedikleri hedefleri organize etmede daha iyidir, dışa dönüktür ve başarı için çaba gösterirler. Benlik saygısı düşük bireyler ise, düşük özgüvene sahip, kendilerini her açıdan eleştiren, yakın ilişkiler kuramayan, kötümser, hata yapmaktan ve başarısızıktan korkan bireylerdir (Öztaş, 2010, s. 322). Bu kişiler reddedilme korkusundan dolayı insanlarla ilişki kurmaktan kaçındıkları için sosyal iletişimleri sınırlanmış olur (Karakuş ve Dereli, 2011, s. 90).

Benlik saygısı, kişinin hem özel hem de mesleki yaşamında çevresine karşı davranış ve tutumlarını belirleyen bir araç vazifesi görür. Hayatın her alanında etkili olan benlik saygısı kişinin mesleki yaşamında özellikle önemlidir (Stresemann, 2010, s. 120). Nitekim yüksek benlik saygısı olan bireylerin kariyer planlama aşamasında daha başarılı oldukları (Choi ve ark., 2012, s. 450; Lin, Wu ve Chen, 2015, s. 13; Weng ve McElroy, 2010, s. 237); buna karşın düşük benlik algısı olan kişilerin kariyer kararları konusunda daha az hazırlıklı oldukları ve daha az mesleki bilgilerinin bulunduğu belirtilmektedir. Düşük benlik saygısı ve yaşam doyumu öğrencilerin

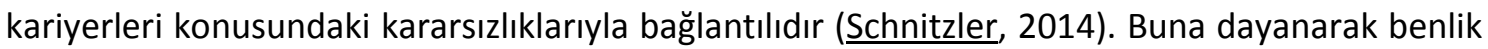
saygısının meslek tercihi ve mesleğe yönelik geliştirilen benlik saygısı üzerinde oldukça önemli bir etkisi bulunduğu söylenebilir.

\subsection{Mesleki Benlik}

Meslek etkinlikleri bireyin kazanç elde etme yoludur. Ancak insan her zaman kazanç elde etmek için değil kapasitesini kullanıp geliştirmekten haz ve doyum sağladığı için de çalışır (Aydın, 2005, s.119).

Meslek seçimi, bireyin yaşamını biçimlendiren en önemli olgulardan biridir ve benlik kavramıyla ayrılmaz bir bağı bulunmaktadır. Çünkü kişiler genellikle benlik algılarıyla ters düşecek meslekleri tercih etmezler. Super (1963) benlik kavramının bireyin davranışlarının belirleyicisi olduğunu belirtmiş ve meslek seçiminin de benlik kavramı tarafından belirlendiğini ileri sürmüştür (Super, 1963'ten aktaran Bacanlı, 2003, s. 338). Bireylerin meslek seçimleri kendi özelliklerini dikkate alarak yapmak durumunda oldukları bir seçimdir. Bireyin kendine uygun bir meslek seçmesi ve mesleğine karşı tutumunun olumlu olması kendini mutlu edeceği gibi toplumun kalkınmasını da sağlayacaktır (Bozdoğan, Aydın ve Yıldırım, 2007, s. 84). 
Benliği ile uyumlu bir mesleğe sahip olan bireylerin daha başarılı, verimli olmaları, kendine güven duyarak, yaptığı işten ve hayattan zevk alması beklenirken (Arıcak ve Dilmaç, 2003, s. 1; Körükçü ve Oğuz, 2011, s. 84), benliği ile uyumsuz bir mesleğe sahip olan bireylerin yaşamlarını çatışma ve doyumsuzluk içinde geçirmeleri oldukça olasıdır (Arıcak ve Dilmaç, 2003, s. 1).

Mesleki benlik saygısı, bireyin tercih ettiği mesleğe karşı geliştirdiği değerlilik yargısıdır ve bireyin kendi mesleğini ne kadar değerli ve saygın gördüğünü ortaya koymaktadır (Demir, Gürsoy ve Ada, 2011, s. 599). Bireyin kendisiyle ilgili kişilik özellikleri, yetenekleri ve onu tatmin edecek kariyer türleri hakkındaki düşünceleri mesleki benlik kavramının temel unsurlarıdır.

Benlik saygısı yüksek olan bireyin mesleğini severek yapması, mesleğe karşı olumlu tutum içinde olması ve mesleğinde başarılı olması daha olasıdır. Bu durum öğretmen adayları açısından daha fazla önem arz eder. Öğretmen adaylarının mesleklerine yönelik tutumları ne kadar olumlu ve mesleki benlik saygıları ne derece yüksek olursa öğretmenlik mesleğini başarılı, verimli ve doyumlu bir şekilde yerine getirmeleri de o ölçüde olası olacaktır (Baloğlu, Karadağ, Çalışkan ve Korkmaz, 2006, s. 350). Özder, Konedralı ve Perkan Zeki (2010) ile Ünal ve Şimşek (2008) çalışmalarında, öğretmen adaylarının mesleği tercih etmelerinin en önemli nedeninin ideallerindeki meslek olması sonucuna varmışlardır. Bu doğrultuda yapılan birçok çalışmada öğretmenlik mesleğini sevdiği için tercih eden öğretmen adaylarının öğretmenliğe yönelik tutumunun daha olumlu olduğu saptanmıştır (Aslan ve Akyol, 2006; Bozdoğan, Aydın ve Yıldırım, 2007; Recepoğlu, 2013).

Toplumsal anlamda gelişimi sağlayabilmenin en etkili yolu o toplumu oluşturan bireylerin kaliteli eğitim almasından geçer. Eğitimin amacına ulaşmasındaki yaşamsal unsurlardan biri olan öğretmenlerin bilişsel becerilere sahip olması gerekliliğinin yanında mesleklerine yönelik olumlu tutumları ve mesleklerine verdikleri değer de çok önemlidir (İncik ve Kılıç, 2014, s. 380). Çünkü öğretmenlerin bu tutum ve davranışları öğrencilerin benlik gelişimleri üzerinde çok etkilidir. Benlik bakımından olumlu algıları bulunan bir öğretmen öğrencilerini olumlu yönde etkileyebilirken, olumsuz algıları olan bir öğretmen ise olumsuz anlamda etkilemesi daha olasıdır. Kişiliği oluşturan en temel özelliklerden birinin de benlik olması dolayısıyla benlik saygısı ve yaptığı mesleğe yönelik değerlerini oluşturan mesleki benlik saygısı yüksek olan öğretmenlerin yetiştireceği öğrencilerin de olumlu kişilik özellikleri geliştirmeleri daha fazla mümkün olacaktır.

Kişiliğe temel özelliklerini veren benlik saygısına tek boyutlu bir yapı ve zaman içinde bireylerin geliştirdiği kararlı ve istikrarlı bir kişilik özelliği olarak yaklaşılmıştır; ancak benlik saygısı belirli sınırlar içinde birçok faktör tarafından etkilenmektedir (Bagana, Raciu ve Lupu, 2011, s. 1332). Benlik kavramının mesleki seçimler aşamasında vücut bulduğu mesleki benlik saygısının kişide olumlu ya da olumsuz gelişmesi de birçok etkene bağlıdır.

Alanyazın incelendiğinde öğretmen adaylarının benlik saygısının (DiStefano ve Motl, 2009; Gül, 2013; Küçükosmanoğlu, 2013; Otacıoğlu, 2009; Önen ve Ulusoy, 2015; Saygın ve Arslan, 2009; Serinkan, Avcık, Kaymakçı ve Alacaoğlu, 2013) ve mesleki benlik saygısının (Arıcak, 1999; Bartan, Oksal ve Sevi, 2013; Demir, Gürsoy ve Ada, 2011; Dursun, Çuhadar ve Tanyeri, 2014; Ünal ve Şimşek, 2008) birçok değişken tarafından etkilendiğine yönelik bulgular mevcuttur. Bu araştırmalarda genellikle tek bir bölümde öğrenim gören öğretmen adaylarının ya benlik saygılarını ya da mesleki benlik saygılarını etkileyen değişkenlerin ele alındığı görülmektedir. Oysaki bir öğretmen adayının gelecekteki mesleğine yönelik tercihlerini yaparken göz önünde bulundurması gereken en önemli kriterlerden biri de mesleğin kendi kişisel özelliklerine uygunluğudur. Benlik saygısının olumlu olması öğretmen adaylarının mesleki benlik saygısının da olumlu yönde gelişmesine zemin hazırlar ve mesleğini daha başarılı 
bir şekilde yürütebilmelerini mümkün kılar. Buradan hareketle araştırma sonucunda öğretmen yetiştirmede ve yetiştirilen öğretmenlerde benlik saygısı oluşturmada önemli bir sorumluluğu bulunan ancak sadece bilgiye yönelik ölçümle öğretmen adayı seçimi yapılan eğitim fakültelerinin programlarındaki eksiklerini gözden geçirmek ve farklı bölümlerde öğrenim gören öğretmen adaylarının benlik ve mesleki benlik saygısı düzeylerine etki eden faktörlerin nasıl sonuçlar yarattığını irdelemek mümkün olabilecektir.

Nitelikli öğretmen yetiştirmenin ilk basamağı mesleğini seven, kendine ve mesleğine dair benlik saygısı yüksek olan öğretmen adayları yetiştirmektir. Bu araştırmada öğretmen adaylarının benlik saygıları ve mesleki benlik saygılarının çeşitli değişkenler açısından incelenmesi amaçlanmıştır. Bu amaç doğrultusunda araştırmanın alt problemleri aşağıda maddelendirilmiştir:

- Öğretmen adaylarının ana bilim dallarına göre benlik saygıları ve mesleki benlik saygılarının incelenmesi

- Öğretmen adaylarının cinsiyetlerine göre benlik saygıları ve mesleki benlik saygılarının incelenmesi

- Öğretmen adaylarının yaşlarına göre benlik saygıları ve mesleki benlik saygılarının incelenmesi

- Öğretmen adaylarının mezun oldukları lise türüne göre benlik saygıları ve mesleki benlik saygılarının incelenmesi

- Öğretmen adaylarının sınıf düzeylerine göre benlik saygıları ve mesleki benlik saygılarının incelenmesi

- Öğretmen adaylarının ailelerinde öğretmen olup olmamasına göre benlik saygıları ve mesleki benlik saygılarının incelenmesi

- Öğretmen adaylarının yükseköğretim program tercih sırasına göre benlik saygıları ve mesleki benlik saygılarının incelenmesi düzeyinin incelenmesi

Öğretmen adaylarının benlik saygısı ile mesleki benlik saygısı arasındaki ilişki

\section{YÖNTEM}

Çalışmanın yöntem bölümü; araştırma modeli, çalışma grubu, veri toplama araçları, verilerin toplanması ve verilerin analizi başlıkları altında sınıflandırılarak açıklanmıştır.

\subsection{Araştırmanın Modeli}

Bu araştırma betimsel araştırma yöntemlerinden ilişkisel tarama türünde bir araştırma olup belirlenmiş alt amaçlar doğrultusunda değişkenler arasındaki ilişki düzeyi istatistiksel testler kullanılarak belirlenmiştir.

\section{2. Çalışma Grubu}

Araştırmanın çalışma grubu tablo 1 'de sunulduğu gibi Çanakkale On sekiz Mart Üniversitesi Eğitim Fakültesi'nde fen bilgisi eğitimi, okul öncesi eğitimi, İngiliz dili eğitimi, Türkçe eğitimi, sınıf eğitimi, bilgisayar ve öğretim teknolojileri eğitimi (BÖTE) ve müzik eğitimi anabilim dallarında öğrenim gören ve tesadüfi küme örnekleme yöntemiyle seçilmiş olan $60^{\prime}$ ar öğrenci olmak üzere toplam 420 öğrenciden oluşmaktadır. 
Tablo 1.

Öğrencilerin Anabilim Dalına Göre Dağılımı

\begin{tabular}{lcc}
\hline Anabilim Dalı & $\mathrm{N}$ & $\%$ \\
\hline Fen Bilgisi Ĕ̆itimi & 60 & 14,3 \\
Okul Öncesi Eğitimi & 60 & 14,3 \\
Ingiliz Dili Eğitimi & 60 & 14,3 \\
Türkçe Eğitimi & 60 & 14,3 \\
Sınıf Eğitimi & 60 & 14,3 \\
BÖTE & 60 & 14,3 \\
Müzik Eğitimi & 60 & 14,3 \\
Toplam & 420 & 100 \\
\hline
\end{tabular}

Tablo 2.

Öğrencilerin Sınıf Düzeyine Göre Dağılımı

\begin{tabular}{lcc}
\hline Sınıf Düzeyi & N & $\%$ \\
\hline 3.Sınıf & 210 & 50 \\
4. Sınıf & 210 & 50 \\
Toplam & 420 & 100 \\
\hline
\end{tabular}

Tablo 2'de sunulan verilere göre öğrencilerin 210'unun (\%50) 3.sınıfta, 210'unun da (\%50) son sınıfta öğrenim görmekte olduğu görülmektedir.

Tablo 3.

Öğrencilerin Cinsiyete Göre Dağılımı

\begin{tabular}{lcc}
\hline Cinsiyet & $\mathrm{N}$ & $\%$ \\
\hline Kadın & 300 & 71,4 \\
Erkek & 120 & 28,6 \\
Toplam & 420 & 100 \\
\hline
\end{tabular}

Tablo 3'te sunulan verilere göre öğrencilerin 300 'ünün $(\% 71,4)$ kız, 120 'sinin $(\% 28,6)$ erkek olduğu tespit edilmiştir.

Tablo 4.

Öğrencilerin Yaşa Göre Dağııımı

\begin{tabular}{lcc}
\hline Yaş & $\mathrm{N}$ & $\%$ \\
\hline $18-22$ & 334 & 79,5 \\
23 ve üstü & 86 & 20,5 \\
Toplam & 420 & 100 \\
\hline
\end{tabular}

Tablo 4'teki verilere göre öğrencilerin 334'ünün $(\% 79,5)$ 18-22 yaş aralığında, 86'sının $(\% 20,5) 23$ ve üzeri yaşta olduğu tespit edilmiştir.

Tablo 5.

Öğrencilerin Mezun Oldukları Lise Türüne Göre Dağılımı

\begin{tabular}{lcc}
\hline Mezun Olunan Lise Türü & $\mathrm{N}$ & $\%$ \\
\hline Düz lise & 113 & 26,9 \\
Dil ağırlıklı lise & 15 & 3,6 \\
Anadolu lisesi & 154 & 36,7 \\
\hline
\end{tabular}




\begin{tabular}{lcc}
\hline Anadolu öğretmen lisesi & 30 & 7,1 \\
Fen lisesi & 6 & 1,4 \\
Meslek lisesi & 102 & 24,3 \\
Toplam & 420 & 100 \\
\hline
\end{tabular}

Tablo 5'teki verilere göre 420 öğrencinin $113^{\prime}$ ü $(\% 26,9)$ düz lise, $15^{\prime}$ i $(\% 3,6)$ dil ağırlıklı lise, 154'i $(\% 36,7)$ Anadolu lisesi, 30'u $(\% 7,1)$ Anadolu öğretmen lisesi, 6’sı $(\% 1,4)$ fen lisesi ve 102 'si $(\% 24,3)$ meslek lisesi mezunudur.

Tablo 6

Öğrencilerin Ailelerinde Öğretmen Olup Olmama Durumuna Göre Dağılımı

\begin{tabular}{lcc}
\hline Ailede Öğretmen Olup Olmama Durumu & $\mathrm{N}$ & $\%$ \\
\hline Var & & 29 \\
Yok & 122 & 71 \\
Toplam & 298 & 100 \\
\hline
\end{tabular}

Tablo 6'daki verilere göre öğrencilerin 122'sinin (\%29) ailelerinde öğretmen olduğu, 298 'inin (\%71) olmadığı tespit edilmiştir.

Tablo 7.

Öğrencilerin Yükseköğretim Tercih Sıralamasına Göre Dağılımı

\begin{tabular}{lcc}
\hline Tercih Sırası & $\mathrm{N}$ & $\%$ \\
\hline $1-5$ & 232 & 55,2 \\
$6-10$ & 111 & 26,4 \\
$10-15$ & 64 & 15,2 \\
15 ve üstü & 13 & 3,1 \\
Toplam & 420 & 100 \\
\hline
\end{tabular}

Tablo 7'de sunulan verilerde öğrencilerin yükseköğretim tercih sıralamalarında 232 'sinin $(\% 55,2)$ öğretmenlik mesleğini ilk 5 tercihinde, 111'inin $(\% 26,4)$ 6-10. tercihleri arasında, 64'ünün (\%15,2) 10-15. tercihleri arasında ve 13'ünün de $(\% 3,1) 15$ ve üstü sıralamada belirttiği görülmüştür.

\subsection{Veri Toplama Araçları}

Araştırma verileri öğretmen adaylarının benlik saygı düzeylerini ölçmek için "Rosenberg Benlik Saygısı Ölçeği”, mesleki benlik saygı düzeylerini ölçmek için "Arıcak Mesleki Benlik Saygısı Ölçeği" ve araştırmacılar tarafından hazırlanan kişisel bilgi formu kullanılarak toplanmıştır.

\subsubsection{Rosenberg Benlik Saygısı Ölçeği}

Çalışma grubunu oluşturan öğretmen adaylarının benlik saygısı düzeyleri Rosenberg Benlik Saygısı Ölçeği kullanılarak belirlenmiştir. M. Rosenberg (1965) tarafından geliştirilen ölçek Füsun Çuhadaroğlu (1986) tarafından ülkemize uyarlanmıştır. Ölçek 63 madde ve 12 alt testten oluşmaktadır. Bu araştırmada 10 maddeden oluşan benlik saygısı alt ölçeği kullanılmıştır. Ölçek, alınabilecek en düşük puanı 10, en yüksek puanı ise 40 olan ve cevapları "çok yanlış" ve "çok doğru" arasında değişen 4'lü Likert tipi bir ölçektir. Yüksek puanlar kişinin benlik saygısının yüksek olduğuna işaret etmektedir (Eskin, Harlak, Demirkıran ve Dereboy, 
2013, s.135). Çuhadaroğlu (1986) tarafından Türkçeye uyarlanan ölçeğin test tekrar test güvenilirliği 0,89, geçerliği ise $0,71^{\prime}$ dir (Demirtaş ve Dönmez, 2006, s. 186).

\subsubsection{Arıcak Mesleki Benlik Saygısı Ölçeği}

Çalışma grubunu oluşturan öğretmen adaylarının mesleki benlik saygısı düzeyleri Arıcak Mesleki Benlik Saygısı Ölçeği kullanılarak belirlenmiştir. Arıcak (1999) tarafından geliştirilen Mesleki Benlik Saygısı Ölçeği bir mesleği tercih etmiş, bir alanda mesleki eğitim gören ya da bir mesleği icra eden 17 yaş ve üstü bireylerin ilgili mesleğe olan saygı tutumlarını ölçmek amacıyla uygulanabilmektedir. Ölçek 30 maddeden oluşmaktadır. Bu 30 maddenin 14'ü olumlu, 16'sı ise olumsuz ifadeleri içermektedir. Olumlu maddelerde "Tamamen Katılıyorum" 5, "Katılıyorum" 4, "Kararsızım" 3, "Katılmıyorum" 2, "Kesinlikle Katılmıyorum" 1 puan alırken olumsuz maddelerde "Tamamen Katılıyorum" 1, "Katılıyorum" 2, "Kararsızım" 3, "Katılmıyorum" 4, "Kesinlikle Katılmıyorum" 5 puan almaktadır. Ölçek puanları 30 ile 150 arasında bir değer vermektedir. Ölçeğin Cronbach Alpha güvenirlik katsayısı 0,90 olarak bulunmuştur (Arıcak, 2001).

Ölçeğin geçerliliği iki şekilde test edilmiştir. Birincisi kapsam geçerliliğidir. Bu geçerlilik türünde, uzman kanısına başvurulmuş ve uzman grubunun $\% 75^{\prime \prime}$ inin kabul ettiği maddeler ölçeğe alınmış, diğerleri ise ölçekten çıkartılmıştır. İkinci yöntem ise yapı geçerliliğini test etmede kullanılan faktör analiz yöntemidir. Sonuç olarak mesleki benlik saygısı ölçeğinin geçerli ve güvenilir bir ölçme aracı olarak kullanılabileceğine karar verilmiştir (Arıcak, 2001).

\subsubsection{Kişisel Bilgi Formu}

Araştırmacılar tarafından düzenlenmiş olan öğretmen adaylarına ait bilgi formu öğrencinin öğrenim gördüğü anabilim dalı, yaşı, cinsiyeti, mezun olduğu lise türü, sınıf düzeyi, yükseköğretim program tercih sırası ve ailesinde öğretmen olup olmama gibi değişkenlerden oluşan toplam altı maddedir.

\subsection{Verilerin Toplanması}

Benlik saygısı ile mesleki benlik saygısı ölçekleri 2016-2017 eğitim öğretim yılının güz döneminde öğrencilere uygulanmıştır. Uygulamalardan önce araştırmanın amacı ve ölçme araçlarının ne şekilde cevaplanacağı konusunda gerekli açıklamalar yapıldıktan sonra ölçekler, araştırmacılar tarafından öğrencilere gruplar halinde sınıf ortamında uygulanmıştır.

\subsection{Verilerin Analizi}

Elde edilen verilerin analizi için SPSS 21.0 paket programı kullanılmıştır. Verilerin değerlendirilmesinde hem betimsel analizler yapılmış hem de değişkenlere göre öğretmen adaylarının benlik saygıları ve mesleki benlik saygılarında farklılık olup olmadığını belirlemek amacıyla $t$ testi ve tek yönlü varyans analizi (ANOVA) kullanılmıştır. Değişkenler arasında anlamlılık düzeyini belirlemek için $\alpha=0,05$ olarak kabul edilmiştir.

Öğretmen adaylarının benlik saygılarının ve mesleki benlik saygılarının düzeyini belirlemek için kullanılan ölçme araçlarındaki puanların normal dağılım gösterip göstermediği Kolmogorov-Smirnov testi ile incelenmiştir. Adayların ölçekteki sorulara verdikleri cevapların puanları ile homojenliğe bakıldığında değerlerin 0,05 'ten küçük olduğu ve normal dağııım göstermediği tespit edilmiştir. Bu nedenle öğretmen adaylarının benlik saygısı ile mesleki benlik saygısı düzeyini belirlemek için kullanılan iki ölçek arasındaki ilişkiyi belirlemek amacıyla Spearman Korelasyon Analizi yapılımıştır. 


\section{BULGULAR}

Bu araştırmada, öğretmen adaylarının benlik saygısı ve mesleki benlik saygılarının anabilim dalı, sınıf düzeyi, yaş, cinsiyet, mezun olunan lise türü, yükseköğretim programı tercih sırası ve ailede öğretmen olma durumu değişkenleri açısından değerlendirilmesi amaçlanmıştır. Araştırma sonucunda benlik saygısı ölçeği ile mesleki benlik saygısı ölçeği puanlarının anabilim dalına göre dağılımı tablo 8 'de sunulmuştur.

Tablo 8.

Benlik Saygısı ve Mesleki Benlik Saygıı Ölçek Puanlarının Anabilim Dalına Göre Betimsel Istatistikleri

\begin{tabular}{llllll}
\hline & \multicolumn{2}{c}{ Benlik SaygıS } & \multicolumn{2}{c}{ Mesleki Benlik Saygısı } \\
\hline Anabilim Dalı & $\mathrm{N}$ & $\bar{X}$ & SS & $\bar{X}$ & SS \\
\hline İngiliz dili eğitimi & 60 & 22,03 & 2,48 & 85,36 & 7,15 \\
Türkçe eğitimi & 60 & 22,30 & 2,17 & 86,60 & 8,77 \\
Müzik eğitimi & 60 & 22,56 & 2,85 & 86,53 & 11,85 \\
Okul Öncesi eğitimi & 60 & 22,70 & 2,53 & 86,43 & 7,34 \\
SInıf eğitimi & 60 & 22,76 & 2,59 & 86,83 & 8,69 \\
BÖTE & 60 & 23,13 & 2,19 & 82,80 & 9,36 \\
Fen bilgisi eğitimi & 60 & 23,40 & 2,40 & 84,51 & 9,91 \\
Toplam & 420 & 22,70 & & 85,58 & \\
\hline
\end{tabular}

Tablo 8 incelendiğinde İngiliz dili eğitimi anabilim dalında okuyan öğrencilerin benlik saygısı ölçeğinden aldıkları puan ortalamasının $\bar{X}=22,03$, Türkçe eğitimi anabilim dalında okuyanların puan ortalamalarının $\bar{X}=22,30$, müzik eğitimi anabilim dalında okuyanların puan ortalamalarının $\bar{X}=22,56$, okul öncesi eğitimi anabilim dalında okuyanların $\bar{X}=22,70$, sınıf eğitimi anabilim dalında okuyanların puan ortalamalarının $\bar{X}=22,76$, bilgisayar ve öğretim teknolojileri eğitimi anabilim dalında okuyanların puan ortalamalarının $\bar{X}=23,13$ ve fen bilgisi eğitimi anabilim dalında okuyanların puan ortalamalarının $\bar{X}=23,40$ olduğu görülmektedir. En yüksek benlik algısına sahip grubun fen bilgisi eğitimi, en düşük benlik algısına sahip grubun Ingiliz dili eğitimi anabilim dalında okuyan öğrenciler olduğu tespit edilmiştir.

Yine tablo 8'deki mesleki benlik saygısı ölçeğinden alınan puanların betimsel istatistiklerine göre en yüksek mesleki benlik saygısına sahip öğretmen adaylarının sınıf eğitimi anabilim dalında, en düşük benlik saygısına sahip öğretmen adaylarının ise bilgisayar ve öğretim teknolojileri anabilim dalında okuyan öğrenciler olduğu belirlenmiştir.

Öğretmen adaylarının benlik saygısı ve mesleki benlik saygısı ölçek puanlarının anabilim dalı ile ilişki durumu tablo 9'da sunulmuştur.

Tablo 9.

Öğretmen Adaylarının Benlik Saygısı ve Mesleki Benlik Saygısı Ölçeği Puanlarının Anabilim Dalına Göre ANOVA Sonuçları

\begin{tabular}{lcccccccc}
\hline & & \multicolumn{3}{c}{ Benlik Saygısı } & \multicolumn{4}{c}{ Mesleki Benlik Saygısı } \\
\hline & $\begin{array}{c}\text { Kareler } \\
\text { toplamı }\end{array}$ & sd & $\begin{array}{c}\text { Kareler } \\
\text { ortalaması }\end{array}$ & $\mathrm{F}$ & $\begin{array}{c}\text { Kareler } \\
\text { toplamı }\end{array}$ & sd & $\begin{array}{c}\text { Kareler } \\
\text { ortalaması }\end{array}$ & $\mathrm{F}$ \\
\hline $\begin{array}{l}\text { Gruplar } \\
\text { arası }\end{array}$ & 78,267 & 6 & 13,044 & 2,133 & 789,167 & 6 & 131,528 & 1,575 \\
$\begin{array}{l}\text { Gruplar içi } \\
\text { Toplam }\end{array}$ & 2525,933 & 413 & 6,116 & & 34480,917 & 413 & 83,489 & \\
\hline
\end{tabular}

Tablo 9'daki analiz sonuçlarına göre, öğretmen adaylarının benlik saygısı düzeyleri arasında öğrenim gördükleri anabilim dalına göre anlamlı bir farklıık bulunmuştur $[F(6,413)=2,133 ; p=0,049<0,05]$. 
Benlik saygısı düzeylerinin hangi anabilim dalları arasında anlamlı farklılık gösterdiğini bulmak için yapılan Scheffe testinin sonuçlarına göre fen bilgisi eğitimi anabilim dalında okuyan öğrencilerin benlik saygılarının $(\bar{X}=23,40)$ İngiliz dili eğitimi bölümünde okuyan öğrencilere nazaran ( $\bar{X}=22,03$ ) daha yüksek olduğu tespit edilmiş; ancak diğer anabilim dalları arasındaki farklılık istatistiksel olarak anlamlı bulunmamıştır.

Öte yandan analiz sonuçlarına göre, öğretmen adaylarının mesleki benlik saygısı düzeyleri arasında öğrenim gördükleri anabilim dalına göre anlamlı bir farklılık bulunmamıştır $[F(6,413)=1,575 ; p=0,153>0,05]$.

Öğretmen adaylarının benlik saygısı ve mesleki benlik saygısı ölçek puanlarının cinsiyetlerine göre dağılımı ve ilişki durumu tablo 3'te verilmiştir.

Tablo 10.

Benlik Saygısı ve Mesleki Benlik Saygısı Ölçeği Puanlarının Cinsiyete Göre T Testi Sonuçları

\begin{tabular}{llllllllll}
\hline & \multicolumn{4}{c}{ Benlik SaygISI } & \multicolumn{4}{c}{ Mesleki Benlik SaygISI } \\
\hline Cinsiyet & $\mathrm{N}$ & $\bar{X}$ & $\mathrm{~S}$ & $\mathrm{sd}$ & $\mathrm{t}$ & $\bar{X}$ & $\mathrm{~S}$ & $\mathrm{sd}$ & $\mathrm{t}$ \\
\hline KIz & 300 & 22,70 & 2,48 & 418 & 0,087 & 86,29 & 8,91 & 418 & 2,53 \\
Erkek & 120 & 22,68 & 2,52 & & & 83,80 & 9,59 & & \\
Toplam & 420 & & & & & & & & \\
\hline
\end{tabular}

Tablo 10'daki verilere göre öğretmen adaylarının benlik saygı düzeyleri cinsiyete göre anlamlı farklılık göstermemektedir $\mathrm{t}(418)=0,087, p=0,931>0.05$. Yine aynı tabloda öğretmen adaylarının mesleki benlik saygısının cinsiyete göre anlamlı farklılık gösterdiği belirlenmiştir $(p=0,012<0.05)$. Analiz sonuçlarına göre kız öğretmen adaylarının mesleki benlik saygıları $(\bar{X}=86,29)$ erkek öğretmen adaylarına nazaran $(\bar{X}=83,80)$ daha yüksektir.

Öğretmen adaylarının yaşlarına göre benlik saygısı ve mesleki benlik saygısı puanlarının dağıımı tablo 11 'de verilmiştir.

Tablo 11.

Benlik Saygısı ve Mesleki Benlik Saygısı Ölçeği Puanlarının Yaşa Göre T Testi Sonuçları

\begin{tabular}{|c|c|c|c|c|c|c|c|c|c|}
\hline \multicolumn{4}{|c|}{ Benlik Saygısı } & \multicolumn{6}{|c|}{ Mesleki Benlik Saygısı } \\
\hline Yaş & $\mathrm{N}$ & $\bar{X}$ & $S$ & sd & $\mathrm{t}$ & $\bar{X}$ & $S$ & sd & $\mathrm{t}$ \\
\hline $18-22$ & 334 & 22,78 & 2,33 & 418 & 1,320 & 85,78 & 8,55 & 418 & 0,898 \\
\hline 23 ve üstü & 86 & 22,38 & 3,03 & & & 84,79 & 11,28 & & \\
\hline Toplam & 420 & & & & & & & & \\
\hline
\end{tabular}

Tablo 11'deki verilere göre öğretmen adaylarının benlik saygı düzeyleri yaşlarına göre anlamlı farklılık göstermemektedir $\mathrm{t}(418)=1,320, p=0,187>0.05$. Yine aynı tabloya göre öğretmen adaylarının mesleki benlik saygı düzeyleri de yaşlarına göre anlamlı farklılık göstermemektedir $\mathrm{t}(418)=0,898, p=0,370>0.05$.

Tablo 12'de öğretmen adaylarının benlik saygısı ve mesleki benlik saygısı ölçeği puanlarının sınıf düzeylerine göre dağılımları sunulmuştur.

Tablo 12.

Benlik Saygısı ve Mesleki Benlik Saygısı Ölçeği Puanlarının Sınıf Düzeyine Göre T Testi Sonuçları

\begin{tabular}{|c|c|c|c|c|c|c|c|c|c|}
\hline \multirow[b]{2}{*}{$\begin{array}{l}\text { Sınıf } \\
\text { Düzeyi }\end{array}$} & \multirow[b]{2}{*}{$\mathrm{N}$} & \multicolumn{4}{|c|}{ Benlik Saygısı } & \multicolumn{4}{|c|}{ Mesleki Benlik Saygısı } \\
\hline & & $\bar{X}$ & $\mathrm{~S}$ & sd & $\mathrm{t}$ & $\bar{X}$ & $S$ & sd & $\mathrm{t}$ \\
\hline $\begin{array}{l}\text { Üçüncü } \\
\text { Sınıf }\end{array}$ & 300 & 22,61 & 2,47 & 418 & 0,704 & 85,24 & 9,20 & 418 & 0,760 \\
\hline Dördüncü Sınıf & 120 & 22,78 & 2,51 & & & 85,92 & 9,15 & & \\
\hline Toplam & 420 & & & & & & & & \\
\hline
\end{tabular}


Tablo 12'deki verilere göre öğretmen adaylarının benlik saygıları sınıf düzeyine göre anlamlı farklılık göstermemiştir $\mathrm{t}(418)=0,704, p=0,482>0,05$. Aynı şekilde öğretmen adaylarının mesleki benlik saygıları da sınıf düzeyine göre farklılık göstermemiştir $t(418)=0,760$, $p=0,448>0,05$.

Öğretmen adaylarının benlik saygısı ile mesleki benlik saygısı puanları ile mezun oldukları lise türü arasındaki ilişki incelenmiş ve sonuçları Tablo 13' te verilmiştir.

Tablo 13.

Benlik Saygısı ve Mesleki Benlik Saygısı Ölçeği Puanlarının Mezun Oldukları Lise Türüne Göre Betimsel istatistikleri

\begin{tabular}{lccccc}
\hline \multirow{2}{*}{ Mezun Olunan Lise Türü } & \multicolumn{3}{c}{ Benlik Saygısı } & \multicolumn{2}{c}{ Mesleki Benlik Saygısı } \\
\cline { 2 - 6 } & $\mathrm{N}$ & $\bar{X}$ & SS & $\bar{X}$ & SS \\
\hline Anadolu Öğretmen Lisesi & 30 & 22,60 & 2,56 & 84,30 & 7,39 \\
Düz Lise & 113 & 22,62 & 2,64 & 84,97 & 10,24 \\
Anadolu Lisesi & 154 & 22,64 & 2,53 & 85,61 & 9,03 \\
Meslek Lisesi & 102 & 22,71 & 2,34 & 85,97 & 9,12 \\
Dil Ağırlıkı Lise & 15 & 23,53 & 2,06 & 87,86 & 6,23 \\
Fen Lisesi & 6 & 23,66 & 2,41 & 90,50 & 5,78 \\
Toplam & 420 & 22,70 & 2,49 & 84,51 & 9,17 \\
\hline
\end{tabular}

Tablo 13 incelendiğinde mezun oldukları lise türüne göre benlik saygısı ölçeği puan ortalaması en yüksek olan grubun fen lisesi mezunu $(\bar{X}=23,66)$, en düşük benlik saygısına sahip grubun ise Anadolu öğretmen lisesi mezunu öğrenciler $(\bar{X}=22,60)$ olduğu görülmektedir.

Benlik saygısı ve mesleki benlik saygısı ölçek puanlarının mezun olunan lise türüne göre ilişki durumu tablo 14'te gösterilmiştir.

Tablo 14.

Öğretmen Adaylarının Benlik Saygııı ve Mesleki Benlik Saygısı Ölçeği Puanlarının Mezun Oldukları Lise Türüne Göre ANOVA Sonuçları

\begin{tabular}{lcccccccc}
\hline & \multicolumn{3}{c}{ Benlik SaygISI } & \multicolumn{3}{c}{ Mesleki Benlik SaygıSı } \\
\hline $\begin{array}{l}\text { Kareler } \\
\text { toplamı }\end{array}$ & sd & $\begin{array}{c}\text { Kareler } \\
\text { ortalaması }\end{array}$ & $\mathrm{F}$ & $\begin{array}{c}\text { Kareler } \\
\text { toplamı }\end{array}$ & sd & $\begin{array}{c}\text { Kareler } \\
\text { ortalaması }\end{array}$ & $\mathrm{F}$ \\
$\begin{array}{l}\text { Gruplar } \\
\text { arası }\end{array}$ & 17,432 & 5 & 3,486 & 0,558 & 330,095 & 5 & 66,019 & 0,782 \\
Gruplar içi & 2586,768 & 414 & 6,248 & & 34939,989 & 414 & 84,396 & \\
Toplam & 2604,200 & 419 & & & 35270,083 & 419 & & \\
\hline
\end{tabular}

Tablo 14'teki analiz sonuçlarına göre, öğretmen adaylarının benlik saygısı düzeyleri arasında mezun oldukları lise türüne göre anlamlı bir farklılık bulunmazken $F(5,414)=0,558$; $p=0,732>0,05$, mesleki benlik saygısı düzeylerinin de mezun oldukları lise türü değişkeninden etkilenmediği belirlenmiştir $\mathrm{F}(5,414)=0,782 ; p=0,563>0,05$.

Öğretmen adaylarının yükseköğretim tercih sıralarının benlik saygısı ve mesleki benlik saygısı ölçek puanlarına etki durumları tablo 15 'te verilmiştir.

Tablo 15.

Benlik Saygısı ve Mesleki Benlik Saygısı Ölçek Puanlarının Tercih Sırasına Göre Betimsel Istatistikleri

\begin{tabular}{llllll}
\hline & \multicolumn{2}{l}{ Benlik SaygISI } & \multicolumn{2}{c}{ Mesleki Benlik SaygISI } \\
\hline Tercih Sırası & N & $\bar{X}$ & SS & $\bar{X}$ & SS \\
\hline $1-5$ & 232 & 22,57 & 2,55227 & 86,48 & 7,98 \\
$6-10$ & 111 & 22,79 & 2,59425 & 85,58 & 8,15
\end{tabular}




$\begin{array}{llllll}10-15 & 64 & 22,57 & 2,56205 & 82,31 & 13,32\end{array}$

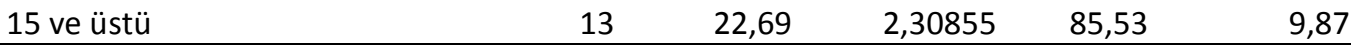

Tablo 15 'teki verilere göre en yüksek benlik saygısı puanı tercih sırası 6-10 arasında olanlarda ( $\bar{X}=22,79$ ) iken en düşük benlik saygısı puanının tercih sırası 1-5 ve 10-15 arasında olanlarda $(\bar{X}=22,57)$ bulunmaktadır. Buna karşın en yüksek mesleki benlik saygısına sahip grubun tercihini ilk 5'te $(\bar{X}=86,48)$, en düşük benlik saygısına sahip grubun ise tercihini 10-15 arasında yapanlarda olduğu belirlenmiştir.

Benlik saygısı ve mesleki benlik saygısı ölçek puanlarının yükseköğretimdeki tercih sırası ile ilişkisi incelenmiş ve analiz sonuçları Tablo 16 'da sunulmuştur.

Tablo 16.

Öğretmen Adaylarının Benlik Saygısı ve Mesleki Benlik Saygııı Ölçeği Puanlarının Yükseköğretimdeki Tercih Sırasına Göre ANOVA Sonuçları

\begin{tabular}{lcccccccc}
\hline & \multicolumn{3}{c}{ Benlik SaygıSı } & \multicolumn{3}{c}{ Mesleki Benlik SaygıSı } \\
\hline & $\begin{array}{c}\text { Kareler } \\
\text { toplamı }\end{array}$ & sd & $\begin{array}{c}\text { Kareler } \\
\text { ortalaması }\end{array}$ & $\mathrm{F}$ & $\begin{array}{c}\text { Kareler } \\
\text { toplamı }\end{array}$ & sd & Kareler & $\mathrm{F}$ \\
ortalaması & \\
\hline $\begin{array}{l}\text { Gruplar } \\
\text { arası }\end{array}$ & 10,442 & 3 & 3,481 & 0,558 & 874,204 & 3 & 291,401 & 3,524 \\
$\begin{array}{l}\text { Gruplar içi } \\
\text { Toplam }\end{array}$ & 2593,758 & 416 & 6,235 & & 34395,879 & 416 & 82,682 & \\
\hline
\end{tabular}

Tablo 16 'daki analiz sonuçlarına göre, öğretmen adaylarının benlik saygısı düzeyleri arasında yükseköğretimdeki tercih sırasına göre anlamlı bir farklııık bulunmamıştır $F(3,416)=0,558 ; p=0,643>0,05$. Ancak öğretmen adaylarının mesleki benlik saygısı düzeyleri arasında yükseköğretimdeki tercih sırasına göre anlamlı bir farklılık bulunmaktadır $F(3,416)=3,524 ; p=0,015<0,05$. Mesleki benlik saygısı düzeylerinin hangi gruplar arasında anlamlı farklılık gösterdiğini bulmak için yapılan Scheffe testinin sonuçlarına göre yükseköğretim tercih sırası 1-5 arasında olan öğretmen adaylarının mesleki benlik saygılarının ( $\bar{X}=86,48)$, tercih sırası 6-10 arasında olanlardan $(\bar{X}=85,58)$ daha yüksek olduğu tespit edilmiştir.

Ailede öğretmen olma durumunun öğretmen adaylarının benlik saygılarına ve mesleki benlik saygılarına etkisi incelenmiş ve sonuçlar tablo $17^{\prime}$ 'de verilmiştir.

Tablo 17.

Benlik Saygısı ve Mesleki Benlik Saygısı Ölçeği Puanlarının Ailede Öğretmen Olup Olmama Durumuna Göre T Testi Sonuçları

\begin{tabular}{|c|c|c|c|c|c|c|c|c|c|}
\hline \multirow[b]{2}{*}{$\begin{array}{l}\text { Ailede Öğretmen } \\
\text { Olma Durumu }\end{array}$} & \multirow[b]{2}{*}{$\mathrm{N}$} & \multicolumn{4}{|c|}{ Benlik Saygısı } & \multicolumn{4}{|c|}{ Mesleki Benlik Saygısı } \\
\hline & & $X$ & $S$ & sd & $\mathrm{t}$ & $\bar{X}$ & $S$ & sd & $\mathrm{t}$ \\
\hline Var & 122 & 22,38 & 2,48 & 418 & 1,659 & 85,12 & 8,23375 & 418 & 0,658 \\
\hline Yok & 298 & 22,82 & 2,52 & & & 85,77 & 9,54001 & & \\
\hline Toplam & 420 & & & & & & & & \\
\hline
\end{tabular}

Tablo 17'deki verilere göre öğretmen adaylarının benlik saygısı düzeyleri ailelerinde öğretmen olup olmama durumuna göre anlamlı farklılık göstermemektedir $\mathrm{t}(418)=1,659, p=$ $0,098>0.05$. Aynı şekilde öğretmen adaylarının mesleki benlik saygısı düzeyleri ailelerinde öğretmen olup olmama durumuna göre de anlamlı farklılık bulunmamaktadır $[\mathrm{t}(418)=0,658$, $p=0,511>0.05]$.

Öğretmen adaylarının benlik saygısı puanları ile mesleki benlik saygısı puanları arasındaki ilişkiye yönelik bulgular tablo $18^{\prime}$ de gösterilmiştir. 
Tablo 18.

Öğretmen Adaylarının Benlik Saygısı Puanları Ile Mesleki Benlik Saygısı Puanları Arasındaki Ilişkiye Yönelik Bulgular

\begin{tabular}{|c|c|c|c|c|}
\hline & & & Benlik saygısı & $\begin{array}{c}\text { Mesleki benlik } \\
\text { saygısı }\end{array}$ \\
\hline \multirow{6}{*}{$\begin{array}{l}\text { Spearman } \\
\text { Korelasyon } \\
\text { Analizi }\end{array}$} & \multirow{3}{*}{ Benlik_Saygısı } & Korelasyon katsayısı & 1,000 & 0,162 \\
\hline & & Sig. (2-tailed) & . & 0,001 \\
\hline & & $\mathrm{N}$ & 420 & 420 \\
\hline & \multirow{3}{*}{ Mesleki Benlik Saygısı } & Korelasyon katsayısı & 0,162 & 1,000 \\
\hline & & Sig. (2-tailed) & 0,001 & \\
\hline & & $\mathrm{N}$ & 420 & 420 \\
\hline
\end{tabular}

Tablo 18 'de görüldüğü gibi değişkenler normal dağılım göstermediği için benlik saygısı ölçeği ile mesleki benlik saygısı ölçeği arasındaki korelasyonun hesaplanmasında Spearman korelasyon analizi yapılmıştır. Araştırmaya katılan öğretmen adaylarının benlik saygısı puanı ile mesleki benlik saygısı puanları arasındaki korelasyon analizine göre iki ölçek arasında zayıf düzeyde de olsa pozitif bir ilişki bulunduğu tespit edilmiştir $[r(420)=0,162 ; p=0,001<0,05]$. Bu doğrultuda öğretmen adaylarının benlik saygıları arttığında mesleki benlik saygı düzeylerinin de artış gösterdiğini söylemek mümkündür.

\section{TARTIŞMA VE SONUÇ}

Düşük benlik saygısı kişinin yaşamında risk faktörü oluşturur. Örneğin geleceğe yönelik olarak zihinsel ve fiziksel sağlığın zayıflığını, ekonomik refah düzeyinin düşüklüğünü, daha yüksek oranda suç faaliyetlerini, anti sosyal davranışları, yeme bozukluklarını, depresyon ve intihar ihtimalini öngörebilir (Erol ve Orth, 2011, s. 607). Bu denli olumsuzlukları bir arada barındıran benlik algısına sahip kişilerin etkileşimde oldukları kişileri de olumsuz anlamda etkileyebilecekleri bir gerçektir. Öğretmen ve sürekli etkileşimde bulunduğu öğrencileri için de aynı durum söz konusudur. Yüksek benlik saygısı olan bir öğretmenin yetiştireceği öğrenciler ile düşük benlik saygısı olan bir öğretmenin yetiştireceği öğrencilerin kişilik ve benlik algıları da birbirinden farklı olacaktır.

Öğretmenin, öğretim dışında öğrencilere rehberlik etmek, bilgiyi nasıl kullanacaklarını öğrenmelerine ve toplumun değerli üyeleri olabilmeleri için hayata uyum sağlamalarına yardımcı olmak gibi bir misyonu da vardır. Bu denli önemli bir misyon ancak kendine ve mesleğine yönelik benlik saygısı yüksek öğretmenlerin üstesinden gelebileceği bir durumdur.

\subsection{Benlik Saygısı ve Anabilim Dalı iliş̧kisi}

Araştırmanın ilk problemi öğretmen adaylarının benlik saygısı düzeylerinin anabilim dalına göre incelenmesidir. Sonuçlara göre, öğretmen adaylarının benlik saygısı düzeyleri arasında anlamlı farklılık fen bilgisi eğitimi ile İngiliz dili eğitimi anabilim dalında okuyanlar arasında ve fen bilgisi eğitimi anabilim dalında okuyan öğrenciler lehine bulunmuştur. Fen bilgisi öğretmen adaylarıyla yapılan çalışmalarda Bahçıvan, Aydın ve Yener (2015) bu bulguyu destekler nitelikte adayların hem özerk hem de ilişkisel benliğe yönelik inançlarının, Yalmancı ve Aydın (2014) ise akademik öz yeterlik düzeylerinin yüksek olduğunu tespit etmiştir. Buldur ve Bursal (2015) fen bilgisi öğretmen adaylarının mesleklerini tercih nedeni ile ilgili yaptıkları çalışmada adayların önceliklerinin dışsal nedenlerden çok özgeci ve içsel nedenler olduğunu, öğretmen adaylarının idealindeki meslek öğretmenlik olduğu için bu alanda seçim yaptıklarını belirtmiştir.

Araştırma sonuçlarına göre kadın öğretmen adaylarının mesleki benlik saygıları erkeklerden daha yüksek bulunmuştur. Bu sonucu destekler nitelikte Anılan ve Anılan (2014)'ın fen bilgisi öğretmen adaylarıyla yaptıkları çalışmada kadın öğretmen adaylarının fen bilgisi 
dersini iyi bir şekilde öğretebileceklerini ve öğretmen olmayı kendilerine daha çok yakıştırdıklarını belirtmiş olması mesleki benlik saygılarının daha yüksek olduğu anlamına gelmektedir.

Araştırma sonuçlarına göre mesleki benlik saygısı erkeklere nazaran daha yüksek olan kadın öğretmen adaylarının sayısı İngiliz dili eğitimine nazaran (\%65) fen bilgisi eğitimi anabilim dalında $(\% 91,6)$ daha fazladır. Buradan hareketle fen bilgisi eğitimi anabilim dalında eğitim alan kadın öğretmen adayının sayıca çokluğu ve araştırma sonuçlarına göre benlik saygısının mesleki benlik saygısını yordama gücü bulunduğu göz önüne alındığında fen bilgisi öğretmen adaylarının benlik saygısı düzeyinin İngiliz dili eğitimine nazaran daha yüksek çıkması beklenen bir sonuçtur.

Latifoğlu (2012) araştırma bulgularının aksine farklı bölümlerde okuyan üniversite öğrencileriyle yaptığı çalışmasında öğrenim gördükleri bölümlerle benlik saygıları arasında anlamlı bir ilişki bulunmadığını belirlemiştir.

\subsection{Benlik Saygısı ve Cinsiyet ílişkisi}

Araştırmanın ikinci problemi öğretmen adaylarının benlik saygı düzeylerinin cinsiyete göre incelenmesidir. Sonuçlara göre benlik saygı düzeyi cinsiyete göre anlamlı farklılık göstermemektedir. Bu bulguya paralel olarak Bano, Anjum ve Pasha (2015), Çelik ve Odacı (2011), Emil (2003), Erol ve Orth (2011), Gündoğdu (2013), Otacıoğlu (2009), Işık (2006), Sevim, Melonashi, Shkembi, Besimi ve Fanaj (2015), Negovan ve Bagana (2011), Duran ve Tezer (2009) ile Yaygın ve Arslan (2009) öğrencilerle yaptıkları çalışmada benlik saygısı ile cinsiyet arasında anlamlı bir ilişkinin olmadığı sonucuna varmışlardır.

Bleidorn ve arkadaşları (2015) hem erkekler hem de kadınlar için benlik saygısının aynı yörüngeleri izlediğini belirtmektedir. Benlik algısındaki bu değişimlerin bireyin aile ve çevre faktörüne dayalı olduğu düşünülmektedir. Yani ailenin tutumu, sosyoekonomik durumu, aile ilgisi ve toplumsal faktörlerin cinsiyete nazaran benlik saygısı üzerinde daha etkili olduğu söylenebilir. Cinsiyet ayrımı yapmayan, kız ya da erkek olsun çocuklarının öğrenimine önem veren bir aile ortamında ve erkeklerle kızların eşit sosyal ve kültürel şartlarda yetiştirildiği bir ortamda büyüyen çocukların benlik algılarının cinsiyetlerine göre farklı olması beklenemez.

Araştırma bulgularının aksine Altıok, Ek ve Koruklu (2010), Arıcak (2007), Arıcak ve Dilmaç (2003), Gül (2013), Küçükosmanoğlu (2013), Latifoğlu (2012) ile Sarıçam, Gençdoğan ve Erözkan (2012) üniversite öğrencilerinin cinsiyetlerinin benlik saygıları arasında farklılık yarattığını ve kız öğrencilerin benlik saygılarının erkek öğrencilere göre daha yüksek olduğunu belirtirken Albo, Núñez, Navarro ve Grijalvo (2007), Başçiftçi, Özen ve Doyduk (2010), DiStefano ve Motl (2009), Frost ve McKelvie (2004), Karakuş ve Dereli (2011), Kong, Ding ve Zhao (2015), Lawrence, Ashford ve Dent (2006) ile Serinkan, Avcık, Kaymakçı ve Alacaoğlu (2014) yaptıkları çalışmalarda erkeklerin benlik saygılarının kızlara nazaran daha yüksek olduğunu tespit etmişlerdir.

\subsection{Benlik Saygısı ve Yaş iliş̧kisi}

Araştırma sonuçlarına göre öğretmen adaylarının benlik saygı düzeyleri yaşlarına göre anlamlı farklılık göstermemektedir. Öngörülen bulgu yaş arttıkça benlik saygı düzeylerinin de artış göstermesi şeklinde ise de mevcut araştırmada yaşın benlik saygısı üzerinde etkili olmadığı sonucu karşımıza çıkmaktadır. Bu bulgular paralelinde Başçiftçi, Özen ve Doyduk (2010), Gündoğdu (2013) ile Negovan ve Bagana (2011) da yaptıkları çalışmalarda benlik saygısı üzerinde yaşın etkili bir faktör olmadığını belirlemişlerdir. 
Araştırmada belirtilen yaş aralıkları birbirine çok yakın olup ergenlik sonrası döneme denk gelmektedir. Ayrıca bu dönemdeki bireylerin benlik ve kişilik gelişimleri tamamlanmış olup bu gelişimlerde bir değişim gözlenmemesi ve yaş aralıklarına göre benlik saygısı puanlarının benzer olması beklenen bir sonuçtur. Ayrıca üniversite ortamı ebeveynden bağımsız olarak yaşama, kendi hayatını kurmaya başlama, kendine yetme, bir mesleğe yönelme gibi durumları beraberinde getirmektedir. Bu zorlukların üstesinden gelebilme işinin, kişinin kendisine yönelik olarak geliştirdiği benlik saygısıyla da ilişkili olduğu, yaşa değil kişinin o ana kadar geçirdiği yaşantılara ve aile içindeki yetiştirilme tutumlarına bağlı olduğu düşünülmektedir.

Araştırma bulgularının aksine Altıok ve arkadaşları (2010), Gül (2013), Otacıoğlu (2009) ile Landine (2013) üniversite öğrencilerinin yaşları ile benlik saygıları arasında anlamlı bir ilişki bulunduğunu ve yaş arttıkça benlik saygılarının da arttığını belirtmiş; Serinkan, Avcık, Kaymakçı ve Alacaoğlu (2014) ise benlik saygısının yaşla birlikte azalma gösterdiğini tespit etmiştir.

\subsection{Benlik Saygısı ve Sınıf Düzeyi ilişkisi}

Öğretmen adaylarının benlik saygıları sınıf düzeyine göre anlamlı farklılık göstermemiştir. Yapılan farklı çalışmalarda da üçüncü ve dördüncü sınıf düzeyinin öğretmen adaylarının benlik saygılarına etkisinin olmadığı yönünde bulgular mevcutken (Başal, Derman ve Kahraman, 2011; Otacıoğlu, 2009) sınıf düzeyinin anlamlı fark yarattığını belirten Altıok ve arkadaşlarının (2010) çalışmasında son sınıfta okuyan öğrencilerin benlik saygılarının daha yüksek olduğu belirtilmiştir. Baş̧̧iftçi, Özen ve Doyduk (2010)'un birinci sınıftan son sınıfa kadar olan öğrencileri dahil ettiği çalışmasında da yine sınıf düzeyinin benlik saygısı üzerinde anlamlı bir farklılık yaratmadığı belirlenmiştir.

Benlik saygısı yaşamın erken dönemlerinde kalıtım ve çevre faktörlerinin etkisiyle oluşmaya başlar ve şekillenir. Bu dönemde ailesi ve çevresi tarafından sevilen, yakınlık ve ilgi gören, değerli hissettirilen çocukta olumlu benlik algısının gelişmesi beklenir. Dolayısıyla yükseköğrenim kurumuna gelene kadarki süreçte zaten oluşmuş olan benlik saygısının sınıf düzeyiyle değil erken dönemlerde ailenin yetiştirme tarzıyla bağlantılı olduğu düşünülmektedir.

\subsection{Benlik Saygısı ve Mezun Olunan Lise Türü Ilişkisi}

Araştırma sonucuna göre öğretmen adaylarının benlik saygısı düzeyleri arasında mezun oldukları lise türüne göre anlamlı bir farklılık bulunmamıştır. Avşaroğlu, Taşğın ve Deniz'in (2007) çalışmaları bu bulguyu desteklemektedir. Araştırmada tüm lise türlerinden mezun öğrencilerin benlik saygısı puanları birbirine yakındır.

Benlik saygısı ile akademik başarı arasındaki pozitif ilişki bulunmaktadır. Gençlik döneminde gösterilen akademik başarı ilerleyen dönemlerdeki genel benlik saygısını olumlu anlamda etkilemektedir (Sarı, 2016, s. 300). Bu nedenle öğrencilerin mezun oldukları lise türünden çok lisedeki öğrenimleri boyunca gösterdikleri akademik başarı düzeyinin, onların üniversite öğrenimlerindeki benlik saygılarını da etkilemiş olabileceği düşünülmektedir.

\subsection{Benlik Saygısı ve Yükseköğretim Tercih Sırası İlişkisi}

Araştırma sonucuna göre yükseköğretimdeki tercih sırası öğretmen adaylarının benlik saygısı düzeyleri arasında anlamlı bir farklıık yaratmamıştır.

Öğrencilerin istedikleri bölümlerde okumasının benlik saygıları üzerinde bir etkisi bulunmamaktadır. Bireyler tercih ettikleri mesleklerin gerektirdiği özelliklerle kendi kişisel özelliklerinin buluştuğu nokta doğrultusunda tercih sıralamasını yapmaktadır. Ancak bu durum, tercihini üst sıralarda yapanların benlik saygısının yüksek, alt sıralarda yapanların benlik saygısının düşük olacağı anlamına gelmemelidir. Örneğin tercihini üst sıralarda yapan 
öğrencilerin bu mesleği yapmayı çok istediği için, alt sıralamalarda yapan öğrencilerin bu tercihini açıkta kalmamak için yapmış olabileceği düşünülebilir. Nitekim Yurdakul, Gür, Çelik ve Kurt'un (2016) araştırmasında öğretmenlerin \%31,3'ünün üniversite puanı yettiği için öğretmenliği seçmek zorunda kaldığını belirtmesi bu kanıyı desteklemektedir. Bu durum her üç öğretmenden birinin mesleğini istemeden seçmek zorunda kaldığı gerçeğini vurgulamaktadır.

\subsection{Benlik Saygısı ve Ailede Öğretmen Olup Olmama Durumu ỉlişkisi}

Araştırma sonucuna göre öğretmen adaylarının benlik saygısı düzeyleri ailelerinde öğretmen olup olmama durumuna göre anlamlı farklılık göstermemektedir. Bebeklik döneminde başlayan ebeveynle ilişkiler çocukta hem güvenli kimlik gelişimiyle sonuçlanmakta hem de ileriki dönemdeki kariyer gelişimine ve alınan kariyer kararına katkıda bulunmaktadır (Dietrich ve Kracke, 2009, s. 109; Vignoli, 2009, s. 92). Benlik ve kimlik gelişimi, ebeveynlerle kurulan ilişkilerin yakınlığı ve niteliğinden etkilenir. Ancak araştırmada aile faktörünün etkisinin bulunmaması benlik oluşumu ve gelişiminde önemli olan kriterin ailenin mesleği değil ailenin çocuğa karşı tutum ve davranışları olduğunu düşündürmektedir.

Özdeşim modeli olan aile, çocuk yetiştirme tutumlarından dolayı çocuklarının benlik saygısını olumlu veya olumsuz olarak etkilemektedir (Dilek ve Aksoy, 2013, s. 97). Çocuğa sevginin ifade edildiği, problemleri ile ilgilenildiği, rehberlik edildiği bir tutum çocuğun benlik saygısını olumlu yönde etkilemektedir. Araştırmada da öğrencilerin benlik saygılarının ortalamanın üzerinde olduğu belirlenmiştir. Bu doğrultuda çocukların benlik saygı düzeylerinin ailede öğretmen olup olmama durumundan değil meslekleri ne olursa olsun anne ve babanın çocuğu yetiştirme biçiminden kaynaklandığı düşünülmektedir.

\subsection{Mesleki Benlik Saygısı ve Anabilim Dalı ilişkisi}

Lisans mezunlarının mezun olduktan sonraki ilk hedefleri bir iş bulmak ve kariyer sahibi olmaktır. Bu planlamanın ilk aşaması lise mezuniyetinden sonraki üniversite sınavında alınan puana göre bir yükseköğretim kurumuna yerleşmektir. Ancak ülkemizde öğrenciler sınav sonucunda açıkta kalmamak için sadece iş kaygısını gidermek ve bir meslek sahibi olmak amacıyla ilgi alanına girmeyen, ön bilgi ve becerilerine sahip olmadığı mesleklere yönelebilmektedirler. Bu durum bireyin ilerideki mesleğine yönelik olumsuz tutumu yanında düşük mesleki benlik saygısını da beraberinde getirmektedir.

Araştırmada bu durumun öğrencilerin öğrenim gördükleri bölümlere göre değişip değişmediği incelenmiş ve öğretmen adaylarının öğrenim gördükleri anabilim dalının mesleki benlik saygısı üzerinde anlamlı farklılık yaratmadığı görülmüştür. Bulguları destekler nitelikte Körükçü ve Oğuz (2011) ile Ünal ve Şimşek (2008) tarafından yapılan çalışmalarda da mesleki benlik saygılarının anabilim dalına göre farklılık göstermediği bulunmuştur. Buna karşın Arıcak (2007) üniversite öğrencilerinin mesleki benlik saygısı düzeylerinde anabilim dalına göre farklılıklar bulunduğunu, meslek saygısı düzeyi en yüksek grubun İngilizce dil eğitimi, en düşük olan grubun ise fizik bölümü öğrencileri olduğunu tespit etmiştir.

Öğretmenlik mesleği, kendi alanında özellikle mesleki bilgi ve yetenek alt yapısı temelinde akademik çalışma ve mesleki performansı gerektiren ve profesyonel anlamda statüsü olan bir meslektir. Her öğretmen, kendi branşı doğrultusunda mevcut bilgi ve becerileri edinmelidir (Canpolat ve Özşaker, 2013, s. 95). Bu doğrultuda tüm anabilim dallarında okuyan öğrencilerin mesleki benlik saygı puanlarının birbirine yakın olması her bir branştaki öğretmen adayının bu bölümü isteyerek seçtiği, mesleği benimsediği ve kendi özellikleriyle uyum içinde olduğunu düşündüğü söylenebilir.

Öğretmen adayları için asıl sorunun mesleğine duyduğu saygı değil ileride mesleğini yapacağı zamandaki koşullar olacağı düşünülmektedir. Nitekim Baloğlu, Çalışkan, Karadağ ve 
Korkmaz (2006)'ın çalışmasında öğretmenlerin mesleklerinin saygınlığından değil mesleğini icra etme koşullarından yani içsel ve dışsal doyum sağlayamadıklarından yakındıkları tespit edilmiştir.

\subsection{Mesleki Benlik Saygısı ve Cinsiyet Illişkisi}

Araştırmada öğretmen adaylarının cinsiyetlerinin mesleki benlik saygılarına etkisi incelenmiş ve cinsiyete göre mesleki benliklerinin anlamlı farklılık gösterdiği, kadın öğretmen adaylarının mesleki benlik saygılarının erkeklere göre daha yüksek olduğu belirlenmiştir. Bulgular paralelinde Arıcak (2007), Arıcak ve Dilmaç (2003), Demir, Gürsoy ve Ada (2011), Uslu (2015) ile Ünal ve Şimşek (2008) tarafından yapılan çalışmalarda cinsiyetin mesleki benlik saygısı puanlar arasında anlamlı farklıık yarattığı ve kız öğrencilerin mesleki benlik saygılarının erkeklere göre daha yüksek olduğu belirlenmiştir.

Öğretmenlik mesleği toplum tarafından bayan mesleği olarak kabul görmektedir. Bu mesleği icra eden kişilerin çoğunluğunun da bayan olduğu görülmektedir. Bayanların bu algıyla doğru orantılı olarak kendi isteğiyle ya da çevre baskısı sonucu meslek tercihlerini öğretmenlikten yana yapmış olmaları muhtemeldir. Öğretmenliğin diğer mesleklere nazaran esnek çalışma saatleri olması, ekonomik bağımsızlık kazanma, uzun tatil süresi ve çocuk sevgisi gibi durumların bayanlar açısından bu mesleği tercih sebepleri olabileceğini düşündürmektedir. Erkeklerin ise kendi benlikleriyle bağdaştıramadıkları öğretmenlik mesleğini seçmek yerine toplumun kendisinden beklediği cinsiyet rollerine uygun meslekleri daha çok tercih ettikleri düşünülmektedir.

Çermik, Doğan ve Şahin'in (2010) yaptığı çalışmada öğretmenlik mesleğini tercih sebebine yönelik olarak erkek öğretmen adaylarının bu seçimi daha çok çıkarcı (öğretmenliği iş garantisi olarak görmeleri, çalışma koşullarının rahatlığı vb.), bayan adayların ise içsel (idealindeki meslek olması ve çocuk sevgisi vb.) nedenlere dayandırdıklarının belirtilmiş olması araştırma bulgularını kanıtlar niteliktedir.

Bulguların aksi yönünde yapılan çalışmalarda ise cinsiyet değişkeninin üniversite öğrencilerinin mesleki benlik saygı düzeylerinde anlamlı farklılık yaratmadığı tespit edilmiştir (Aral ve ark., 2009; Bartan, Oksal ve Sevi, 2013; Dursun, Çuhadar ve Tanyeri, 2014; Işık, 2006; Kurt ve Gürlen, 2016).

\subsection{Mesleki Benlik Saygısı ve Yaş iliş̧kisi}

Sonuçlara göre öğretmen adaylarının mesleki benlik saygı düzeyleri yaşlarına göre anlamlı farklılık göstermemektedir. Artan yaşa bağıı olarak bireylerin kendi özelliklerini daha iyi tanıyacağı varsayılırsa da yaşın benlik saygısı düzeyinde farklıılı yaratacak etkisi bulunmamıştır. Burada her iki yaş grubunun da üniversite eğitimine başlamadan önce mesleğine yönelik bir bilgi birikimi ile geldikleri ve bilinçli bir tercih yaptıkları varsayılabilir.

Başçifţ̧i, Özen ve Doyduk'un (2010) çalışması araştırma bulgusunun aksine farklı yaş grubundaki bireyler arasında mesleki benlik saygısı düzeyinin de farklı olduğu yönündedir.

\subsection{Mesleki Benlik Saygısı ve Sınıf Düzeyi İlişkisi}

Araştırma sonuçlarına göre öğretmen adaylarının mesleki benlik saygıları sınıf düzeyine göre anlamlı farklılık göstermemiştir. Aslan ve Akyol (2006) ile Körükçü ve Oğuz (2011) aynı paralellikteki bulguları ile sınıf düzeyinin mesleki benlik saygılarına etkisinin olmadığını belirtmiştir. Buna karşın Bartan, Oksal ve Sevi (2013) ile Demir, Gürsoy ve Ada'nın (2011) çalışmasındaki bulgular dördüncü sınıf öğrencilerinin birinci sınıflara nazaran mesleki benlik saygılarının daha düşük olduğu yönündedir. 
Mesleki benlik kavramının sınırları bireyin yükseköğretim tercihiyle belirmeye başlar, aldığı mesleki eğitimle daha da netleşir ve nihayetinde mesleki pratikle sağlamlaşır (Arıcak, 2007). Bu durumun son sınıfların lehine olması gerekirken araştırmada sınıf düzeyinin belirleyici etkisinin bulunmaması ve her iki sınıf düzeyinde de mesleki benlik saygısı düzeylerinin ortalamanın üzerinde olması öğrencilerin üçüncü ve dördüncü sınıflarda alanlarıyla ilgili yaptıkları pratikler sonucu mesleklerini daha iyi tanıdıklarını ve mesleklerine dair benzer olumlu bir algı geliştirdiklerini düşündürmektedir.

\subsection{Mesleki Benlik Saygısı ve Mezun Olunan Lise Türü ilişkisi}

Araştırmada mesleki benlik saygısı düzeylerinin mezun oldukları lise türü değişkeninden etkilenmediği belirlenmiştir. Demir, Gürsoy ve Ada (2011), Körükçü ve Oğuz (2011) ile Uslu (2015) yaptıkları çalışmalarda aynı bulgulara ulaşmış ve öğrencilerin mezun oldukları lise türünün mesleki benlik saygıları üzerinde anlamlı bir farklılık yaratmadığını belirtmiştir. Bunun nedeni öğretmenlik mesleğinin hangi lise mezunu olursa olsun tercih edilen ve saygın bir meslek olarak görülmesi olabilir.

Araştırmada fen lisesi mezunlarının mesleki benlik saygılarının en yüksek düzeyde olması, daha önceki bulgularda en yüksek benlik saygısına sahip grubun fen bilgisi eğitimi anabilim dalında okuyanlar olması ile ilişkilendirilebilir. Bu durum program öğrencilerinin üniversite tercihlerini de bilinçli olarak yaptıklarına, mesleğe hazır bulunuş ve mesleki benlik saygısı düzeylerinin yüksek oluşuna bir kanıt olabilir.

\subsection{Mesleki Benlik Saygısı ve Yükseköğretimdeki Tercih Sırası Ilişkisi}

Araştırma sonucuna göre yükseköğretimdeki tercih sırası öğretmen adaylarının mesleki benlik saygıları üzerinde anlamlı bir farklıık yaratmıştır. Analiz sonuçlarına göre yükseköğretim tercih sırası 1-5 arasında olan öğretmen adaylarının mesleki benlik saygılarının, tercih sırası 610 arasında olanlardan daha yüksek olduğu tespit edilmiştir. Bulguyu destekleyen araştırmalarda Arıcak (2007), Kurt ve Gürlen (2016) ile Uslu (2015) bölüm tercihleri ilk sırada olan üniversite öğrencilerinin mesleki benlik saygılarının daha yüksek olduğunu belirtmiştir.

Öğretmen adaylarının ileride yapacakları mesleklerine yönelik hazırbulunuşluk düzeylerinin ilk belirteci üniversite sınavı sonrasında yaptıkları meslek tercihleridir. Bu aşamada adaylar kendi özellikleriyle en çok uyuştuğunu düşündükleri, en çok sevdiği ve yapmak istediği mesleği tercih sıralamasında en üst sıralara yerleştirmektedir. Araştırmada öğretmenlik tercihini ilk 5 sırada yapan öğrencilerin bu bölümde okumayı çok istediği için seçtikleri düşünülmektedir. Kendi seçtiği yükseköğretim kurumunda yine kendi seçtiği mesleğiyle ilgili aldığı eğitim süresince öğrenciler hem kendi kişisel özelliklerini hem de mesleğine karşı tutumlarını değerlendirme fırsatı bulmaktadır. Aldığı eğitimden doyum sağlayan bireylerin zaten severek tercih ettiği mesleğine yönelik benlik saygısının da olumlu olacağı kaçınıımazdır. Özbek (2007) tarafından yapılan çalışmada öğretmen adaylarının öğretmenlik mesleğini tercih etmelerinde öğretmenliğin sosyal ve ekonomik getirisinden çok öğretmenliği ideal ve kutsal bir meslek olarak görmeleri ve çocukları çok sevmeleri gibi kişisel sebeplerin daha belirleyici olduğu belirlenmiştir. Meslek tercihini yükseköğretime girişte son sıralarda yapan öğrencilerin bu tercihi bir iş bulma kaygısıyla ve aile ya da çevre baskısı neticesinde yaptığı tespit edilmiştir (Sarıkaya ve Khorshid, 2009, s. 418).

Bulguların aksine Aral, Gürsoy, Ceylan ve Bıçakçı (2009), Dursun, Çuhadar ve Tanyeri (2014) ile Körükçü ve Oğuz (2011) araştırmalarında tercih sıralarının mesleki benlik düzeylerinde önemli bir farklılık yaratmadığını belirlemiştir. 


\subsection{Mesleki Benlik Saygısı ve Ailede Öğretmen Olup Olmama Durumu İlişkisi}

Araştırmada öğretmen adaylarının ailelerinde öğretmen olup olmama durumunun mesleki benlik saygısı düzeylerini etkilemediği bulunmuştur. Bulguyu destekleyen çalışmalarda Bartan, Oksal ve Sevi (2013), Körükçü ve Oğuz (2011) ile Uslu (2015) ailede öğretmen olma durumunun öğretmen adaylarının mesleki benlik saygılarında önemli bir farklılığa yol açmadığını tespit etmişlerdir. Araştırmaya göre ailede öğretmen olsun ya da olmasın öğrencilerin öğretmenliği tercih edilen ve toplumsal statüsü güçlü olan bir meslek olarak gördükleri için seçtikleri düşünülebilir. Diğer yandan eskiden olduğu gibi bireyin seçeceği meslek aile mesleğinin devamı gibi düşünülmemekte; birey kendi ilgi alanı ve yeteneklerine uygun meslekleri seçmektedir.

Araştırmadaki bulgunun aksine Vignoli (2009) yaptığı çalışmada ailelerin çocuklarının psikososyal gelişimlerinde ama özellikle kariyer gelişiminde önemli bir rol oynadıklarını ve öğrencilerin de mesleki tercihlerini anne ve babalarına bağlı olarak daha kolay aldıklarını belirlemiştir. Bu doğrultuda Aslan ve Akyol'un (2009) çalışmasında öğretmen adaylarının mesleki benlik saygısı üzerinde ailede öğretmen olmasının anlamlı farklıık yarattığı belirlenmiştir.

\subsection{Benlik Saygısı ile Mesleki Benlik Saygısı Arasındaki iliş̧ki Durumu}

Araştırmaya katılan öğretmen adaylarının benlik saygısı puanı ile mesleki benlik saygısı puanları arasındaki korelasyon analizine göre iki ölçek arasında zayıf düzeyde de olsa pozitif bir ilişki bulunduğu tespit edilmiştir. Yani öğretmen adaylarının benlik saygıları arttığında mesleki benlik saygı düzeylerinin de artış gösterdiğini söylemek mümkündür. Bu bulgu doğrultusunda öğretmen adaylarının ileride yapmayı düşündükleri öğretmenlik mesleği ile kişilik özellikleri arasında uyumu yakaladığı söylenebilir. Aynı bulgular paralelinde Arıcak ve Dilmaç (2003) ile Öztaş (2010) da çalışmalarında üniversite öğrencilerinin benlik saygısı ile mesleki saygısı arasında anlamlı pozitif bir ilişki bulunduğunu tespit etmişlerdir.

Köroğlu (2014) üniversite öğrencileriyle yaptığı çalışmada meslek seçimi ile kişilik özelliği arasında olumlu düzeyde bir ilişki olduğunu belirlemiştir. Işık (2006) da aynı şekilde öğretmenlik mesleğini kişilik özelliklerine uygun bulan öğretmen adaylarının benlik kavramları ile mesleki benlik kavramları arasında anlamlı bir ilişki bulunduğunu belirtmiştir. Çünkü bireyin, kişiliğine uygun düşen meslekleri seçtiği sürece yaşamdan ve yaptığı işten doyum sağlayabileceği düşünülmektedir.

$\mathrm{Bu}$ araştırmada eğitim fakültesinde öğrenim gören öğretmen adaylarının benlik saygıları ile mesleki benlik saygılarının birbiriyle ilişkilerini ortaya koymak ve anabilim dalı, yaş, cinsiyet, sınıf düzeyi, mezun oldukları lise türü, yükseköğretimi tercih sırası ve ailede öğretmen olup olmama durumu değişkenlerinden etkilenme durumunu belirlemek amaçlanmıştır. Sonuç olarak öğretmen adaylarının benlik saygısı düzeyleri arasında anlamlı farklılı̆ın fen bilgisi eğitimi ile İngiliz dili eğitimi anabilim dalında okuyanlar arasında ve fen bilgisi eğitimi anabilim dalında okuyan öğrencilerin lehine olduğu, cinsiyet, yaş, sınıf düzeyi, mezun olunan lise türü, yükseköğretimi tercih sırası ve ailede öğretmen olup olmama durumu değişkenlerinin benlik saygısı üzerinde anlamlı fark yaratmadığı belirlenmiştir. Mesleki benlik saygısı düzeylerinin anabilim dalı, yaş, sınıf düzeyi, mezun oldukları lise türü ve ailede öğretmen olup olmama değişkenlerinden etkilenmediği; ancak cinsiyet ve yükseköğretimdeki tercih sırası değişkenlerine göre anlamlı değişim gösterdiği tespit edilmiştir. Öğretmen adaylarının benlik saygı düzeylerinin mesleki benlik saygı düzeylerini yordadığı araştırmada ortaya çıkan bir diğer sonuçtur. 


\section{KAYNAKÇA}

Adler, N. \& Stewart, J. (2004). Self esteem. Psychosocial Notebook. The MacArthur Research Network on Socioeconomic Status and Health. 15 Ocak 2017 tarihinde http://www.macses.ucsf.edu/research/psychosocial/selfesteem.php adresinden erişilmiştir.

Albo, J. M., Núñiez, J. L., Navarro, J. G. \& Grijalvo, F. (2007). The Rosenberg self-esteem scale: Translation and validation in university students. The Spanish Journal of Psychology. 10(2), 458-467.

Altıok, H., Ek, N. \& Koruklu, N. (2010). Üniversite öğrencilerinin benlik saygı düzeyi ile ilişkili bazı değişkenlerin incelenmesi. Adnan Menderes Üniversitesi Eğitim Fakültesi Eğitim Bilimleri Dergisi. 1(1), 99-120.

Anılan, B. ve Anılan, H. (2014). Fen bilgisi öğretmen adaylarının fen bilgisi öğretmenliğini seçme nedenleri ve gelecek beklentileri. Eğitim ve Öğretim Araştırmaları Dergisi. 3(3), 51-64.

Aral, N., Gürsoy, F., Ceylan, R. \& Bıçakçı, M. Y. (2009). Examination of the professional selfesteem of teacher candidates studying at a faculty of education. Policy Futures in Education. 7(4), 423-429.

Arıcak, T. (1999). Öğretmen adaylarının benlik saygısı ve mesleki benlik saygılarının geliştirilmesine yönelik bir grupla psikolojik danışma uygulaması. M.Ü. Atatürk Eğitim Fakültesi Eğitim Bilimleri Dergisi. 11, 11-22

Arıcak, T. (2001). Mesleki benlik saygısı ölçeğinin geliştirilmesi, güvenirlik ve geçerlik çalışmaları. 6. Ulusal Psikolojik Danışma ve Rehberlik Kongresi. Orta Doğu Teknik Üniversitesi, 5-7 Eylül 2001, Ankara. s. 5-7.

Arıcak, T. (2007). The investigation of Turkish university students' vocational self-esteem levels within different academic departments. California Association for Counseling and Development Journal. 22, 21-33.

Arıcak, T. \& Dilmaç, B. (2003). Psikolojik danışma ve rehberlik öğrencilerinin bir takım değişkenler açısından benlik saygısı ile mesleki benlik saygısı düzeylerinin incelenmesi. Trakya Üniversitesi Sosyal Bilimler Dergisi. 3(1), 1-7.

Aslan, D. \& Akyol, A.K. (2006). Okul öncesi öğretmen adaylarının öğretmenlik mesleğine yönelik tutumları ve mesleki benlik saygılarının incelenmesi. Çukurova Üniversitesi Sosyal Bilimler Enstitüsü Dergisi. 15(2), 51-60.

Avşaroğlu, S., Taşğın, Ö. \& Deniz, M. (2007). Üniversite öğrencilerinin benlik saygısı düzeylerinin bazı değişkenler açısından incelenmesi. XVI. Ulusal Eğitim Bilimleri Kongresi. Gaziosmanpaşa Üniversitesi Eğitim Fakültesi, 5-7 Eylül 2007, Tokat.

Aydın, D. (2005). Mesleki Rehberlik. (Ersin Uzman (Ed.), Psikolojik Danışma ve Rehberlik içinde (s.118-142). İstanbul: Lisans Yayıncılık.

Bacanlı F. (2003). Mesleki grup rehberliğinin benlik ve meslek kavramlarının bağdaşımına etkisi. Kuram ve Uygulamada Eğitim Yönetimi. 9(35), 336-359.

Bagana, E., Raciu, A. \& Lupu, L. (2011). Self esteem, optimism and exams' anxiety among high school students. Procedia - Social and Behavioral Sciences. 30, 1331 - 1338.

Bahçıvan, E., Aydın, F. \& Yener, D. (2015). Fen bilgisi öğretmen adaylarının teknolojik pedagojik alan bilgisi öz güvenleri ve benlik kurguları arasındaki ilişkilerin incelenmesi: Abant İzzet 
Baysal Üniversitesi örneği. Abant İzet Baysal Üniversitesi Eğitim Fakültesi Dergisi. 15(2), 1-12.

Baloğlu, N. , Karadağ, E., Çalışkan, N. ve Korkmaz, T. (2006). Ilköğretim öğretmenlerinin mesleki benlik saygısı ve iş doyumları arasındaki ilişkinin değerlendirilmesi. Ahi Evran Üniversitesi Kırşehir Eğitim Fakültesi Dergisi (KEFAD). 7(2), 345-358.

Bano, H., Anjum, N. \& Pasha, S. (2015). Differences in self-esteem of university students with and without disability. Journal of Educational Research. 18(1), 114.

Bartan, M., Oksal, A. \& Sevi, L. (2013). Analysis of attitudes of preschool prospective teachers towards teaching profession and their professional self-esteem (Kütahya sample). Ozean Journal of Social Sciences. 6(2), 35-42.

Başal, H.A., Derman, M. T. ve Kahraman, P. B. (2011). Aggression and self-esteem levels of preschool and primary school teacher candidates and their relations with certain variable. Management and Education, 7(4), 277-287.

Başçiftçi, F., Özen, S. \& Doyduk, A. (2010). Selçuk Üniversitesi Teknik Eğitim Fakültesi öğrencilerinin benlik ve mesleki benlik saygılarının incelenmesi. e-Journal of New World Sciences Academy Education Sciences. 5(4), 2198-2205.

Bleidorn, W., Arslan, R. C., Denissen, J. J. A., Rentfrow, P. J., Gebauer, J. E., Potter, J. \& Gosling, S. D. (2015). Age and gender differences in self-esteem-a cross-cultural window. Personality Processes and Individual Differences. 111(3), 396-410.

Bozdoğan, A. E., Aydın, D. ve Yıldırım, K. (2007). Öğretmen adaylarının öğretmenlik mesleğine ilişkin tutumları. Ahi Evran Üniversitesi Kırşehir Eğitim Fakültesi Dergisi (Kefad). 8(2), 83-97.

Buldur, S. \& Bursal, M. (2015). The impact levels of career choice reasons of preservice science teachers and their future career expectations. Necatibey Eğitim Fakültesi Elektronik Fen ve Matematik Eğitimi Dergisi. 9(1), 81-107.

Canpolat, A. M. \& Özşaker, M. (2013). Physical education candidate teachers' beliefs about vocational self-esteem. Turkish Journal of Sport and Exercise. 15(2), 94-99.

Choi, B. Y., Park, H. Yang, E., Lee, S. K., Lee, Y. \& Lee, S. M. (2012). Understanding career decision self-efficacy: A meta-analytic approach. Journal of Career Development. 39(5), 443-460.

Cüceloğlu, D. (2006). Insan ve Davranışı (15.bs.). İstanbul: Remzi Kitabevi

Çelik, H. B. \& Odacı, H. (2011). Öğretmen adaylarının kendilik algılarını yordayıcı olarak boyun eğici davranışlar. E-Journal of New World Sciences Academy. 6(2), 1388-1396.

Demir, V., Gürsoy, F. \& Ada, Ş. (2011). Okul öncesi öğretmen adaylarının mesleki benlik saygılarının incelenmesi. Gaziantep Üniversitesi Sosyal Bilimler Dergisi. 10(1), 597-614.

Demirtaş, A. \& Dönmez, A. (2006). Yakın ilişkilerde kıskançlık: Bireysel, ilişkisel ve durumsal değişkenler. Türk Psikiyatri Dergisi. 17(3), 181-191.

Deniz, M. E. (2006). The relationships among coping with stress, life satisfaction, decisionmaking styles and decision self-esteem: An investigation with Turkish university students. Social Behavior and Personality: An International Journal. 34(9), 1161-1170.

Dietrich, J. \& Kracke, B. (2009). Career-specific parental behaviors in adolescents' development. Journal of Vocational Behavior. 75(2),109-119. 
Dilek, H. \& Aksoy, A. B. (2013). Ergenlerin benlik saygısı ile anne-babalarının benlik saygısı arasındaki ilişkinin incelenmesi. Ahi Evran Üniversitesi Kırşehir Eğitim Fakültesi Dergisi. 14(3), 95-109.

DiStefano, C. \& Motl, R. M. (2009). Self-esteem and method effects associated with negatively worded items: Investigating factorial invariance by sex. Structural Equation Modeling. 16(1),134-146.

Duran, N. O. \& Tezer, E. (2009). Wellness and self-esteem among Turkish university students. International Journal for the Advancement of Counselling. 31(1), 32-44.

Dursun, Ö. Ö., Çuhadar, C. \& Tanyeri, T. (2014). Bilişim teknolojileri öğretmen adaylarının mesleki benlik saygıları. Pamukkale Üniversitesi Eğitim Fakültesi Dergisi. 35 (1), 131142.

Emil, S. (2003). Self-esteem and stressful life events of university students (Yayımlanmamış Yüksek Lisans Tezi). Orta Doğu Teknik Üniversitesi, Ankara.

Erol, Y. \& Orth, U. (2011). Self-esteem development from age 14 to 30 years: A longitudinal study. Journal of Personality and Social Psychology. 101(3), 607-619.

Eskin, M., Harlak, H., Demirkıran, F. \& Dereboy, Ç. (2013). Algılanan stres ölçeğinin Türkçeye uyarlanması: Güvenirlik ve geçerlik analizi. New/Yeni Symposium Journal. 51(3), 132140.

Frost, J. \& McKelvie, S. (2004). Self-esteem and body satisfaction in male and female elementary school, high school and university students. Sex Roles. 51(1), 45-54.

Gül, H. (2013). Üniversite öğrencilerin öz saygı düzeylerinin bazı değişkenlere göre incelenmesi. Hacettepe Üniversitesi Eğitim Fakültesi Dergisi. 28(2), 194-205.

Gündoğdu, R. (2013). Investigation of self-handicappıng tendencies of teacher candidates according to demographic variables by controlling self-esteem scores. Turkish Studies International Periodical For The Languages, Literature and History of Turkish or Turkic. 8(3), 263-277.

Işık, E. N. (2006). Öğretmen adaylarının benlik kavramları ile mesleki benlik kavramları arasındaki bağdaşımın bazı değişkenlere göre incelenmesi: Selçuk Üniversitesi Örneği (Yayımlanmamış Yüksek Lisans Tezi). Selçuk Üniversitesi, Konya.

İncik, E. Y., \& Kılıç F. (2014). Attitudes regarding the teaching profession, professional efficacy beliefs and vocational self-esteem of teacher canditates enrolled at education faculties and pedagogic formation programmes. International Journal of Social Science and Education. 4 (2), 380-391.

Karakuş, Ö. \& Dereli, E. (2011). Öğretmen adaylarının benlik saygısı ve stresle başa çıkma stillerinin incelenmesi. E-international Journal of Educational Research. 2(4), 89-104.

Kong, F., Ding, K. \& Zhao, J. (2015). The relationships among gratitude, self-esteem, social support and life satisfaction among undergraduate students. Journal of Happiness Studies. 16(2), 477-489.

Köroğlu, Ö. (2014). Meslek seçimi ile kişilik özellikleri arasındaki ilişkinin belirlenmesi: turizm rehberliği öğrencileri üzerine bir araştırma. Süleyman Demirel Üniversitesi Iktisadi ve idari Bilimler Fakültesi Dergisi. 19(2), 137-157.

Körükçü, Ö. \& Oğuz, V. (2011). Okul öncesi eğitimi öğretmen adaylarının mesleki benlik saygıları. Kuramsal Eğitimbilim. 4(2), 77-85. 
Kurt, D. \& Gürlen, E. (2016). Predicting vocational self-esteem of prospective teachers. Ahi Evran Üniversitesi Kırşehir Eğitim Fakültesi Dergisi. 17(2), 207-221.

Küçükosmanoğlu, H. O. (2013). Müzik öğretmeni adaylarının bazı sosyodemografik değişkenlere göre benlik saygısı düzeylerinin karşılaştırılması. Sanat Eğitimi Dergisi. 1(2), 70-82.

Landine, J. R. (2013). The relationship between vocational self-concept crystallization, egoidentity status, and occupational Indecision, as mediated by rational or experiential processing. Canadian Journal of Counselling and Psychotherapy. 50(1), 5-18.

Latifoğlu, G. (2012). Üniversite öğrencilerinin benlik saygısı düzeyleri ile sosyal becerileri arasındaki ilişkinin değerlendirilmesi. Hacettepe Üniversitesi Eğitim Fakültesi Dergisi. 2(Özel Sayı), 55-64.

Lawrence, J., Ashford, K. \& Dent, P. (2006). Gender differences in coping strategies of undergraduate students and their impact on self-esteem and attainment. Active Learning in Higher Education. 7(3), 273-281.

Lin, S. H., Wu, C. H. \& Chen, L. H. (2015). Unpacking the role of self-esteem in career uncertainty: A self-determination perspective. Journal of Positive Psychology. 10 (3), 231-239.

Negovan, V. \& Bagana, E. (2011). A comparison of relationship between self esteem and vulnerability to depression among high school and freshmen university students. Procedia - Social and Behavioral Sciences. 30, 1324-1330.

Otacıŏ̆lu, S. G. (2009). Müzik öğretmeni adaylarının benlik saygısı düzeyleri ile akademik ve çalgı başarılarının karşılaştırılması. Dicle Üniversitesi Ziya Gökalp Eğitim Fakültesi Dergisi. 13, 141-150.

Önen, A. S. \& Ulusoy, F. M. (2015). The relationship between pre-service teachers' self-esteem and emotional intelligence levels. Procedia - Social and Behavioral Sciences. 186, 11631168.

Özbek, R. (2007). Öğretmen adaylarının öğretmenlik mesleğini tercih etmelerinde kişisel, ekonomik ve sosyal faktörlerin etkililik derecesine ilişkin algıları. Fırat Üniversitesi Sosyal Bilimler Dergisi. 17(1), 145-159.

Özdemir, O., Özdemir, P. G., Kadak, M. T. \& Nasıroğlu, S. (2012). Kişilik gelişimi. Psikiyatride Güncel Yaklaşımlar. 4(4), 566-589.

Özder, H., Konedralı, G. \& Zeki, C. P. (2010). Öğretmen adaylarının öğretmenlik mesleğine yönelik tutumlarının çeşitli değişkenler açısından incelenmesi. Kuram ve Uygulamada Eğitim Yönetimi. 16(2), 253-275.

Öztaş, F. (2010). Self-esteem, occupational self-esteem, and epistemological beliefs of Turkish university students. Social Behavior and Personality. 38(3), 321-326.

Pasha, H. S. \& Munaf, S. (2013). Relationship of self-esteem and adjustment in traditional university students. Procedia - Social and Behavioral Sciences. 84, 999-1004.

Recepoğlu, E. (2013). Öğretmen adaylarının yaşam doyumları ile öğretmenlik mesleğine ilişkin tutumları arasındaki ilişkinin incelenmesi. Hacettepe Üniversitesi Eğitim Fakültesi Dergisi. 1(özel sayı), 311-326.

Sarı, E. (2016). Özgüven Duygusu. Antalya: NoktaE-book. 
Sarıçam, H., Gençdoğan, B. \& Erözkan, A. (2012). The examination of the relationship between the university students' rejection sensivities, self esteem and loneliness levels. Procedia - Social and Behavioral Sciences. 46, 2716-2720.

Sarıkaya, T. \& Khorshid, L. (2009). Üniversite öğrencilerinin meslek seçimini etkileyen etmenlerin incelenmesi: Üniversite öğrencilerinin meslek seçimi. Türk Eğitim Bilimleri Dergisi. 7(2), 393-423.

Saygın, Y. \& Arslan, C. (2009). Üniversite öğrencilerinin sosyal destek, benlik saygısı ve öznel iyi oluş düzeylerinin incelenmesi. Selçuk Üniversitesi Ahmet Keleşoğlu Eğitim Fakültesi Dergisi. 28, 207-222.

Schnitzler, A. (2014). Low self-esteem as a barrier for career exploration in adolescents. ECER 2014, The Past, the Present and the Future of Educational Research Conference 3 Eylül 2014. Germany. 17 Ocak 2017 tarihinde http://www.eera-ecer.de/ecerprogrammes/conference/19/contribution/32897/ adresinden erişilmiştir.

Serinkan, C., Avcık, C., Kaymakçı, K. \& Alacaoğlu, D. (2013). Determination of students selfesteem levels at Pamukkale University. Procedia - Social and Behavioral Sciences. 116(21), 4155-4158.

Sevim M., Melonashi, E., Shkembi, F., Besimi, K. \& Fanaj, N. (2015). Anxiety and self-esteem among university students: Comparison between Albania and Kosovo. Procedia - Social and Behavioral Sciences. 205, $189-194$.

Stresemann, E. (2010). Self-esteem in occupational life. Versicherungsmedizin. 62(3), 120-121.

Super, D. E. (1963). Toward making self-concept theory operational. D. E. Super, J. P. Jordan, N. Maitlin, \& R. Starishevsky (Eds.), Career development: Self concept theory. NYC: College Entrance Examination Board.

Thomaes, S., Poorthuis, A. \& Nelemans, S. (2011). Self-esteem. B. B. Brown \& M. Prinstein (Eds.), Encyclopedia of Adolescence içinde (s. 316-324). Amsterdam: Elsevier.

Uslu, S. (2015). Sosyal bilgiler öğretmen adaylarının mesleki benlik saygılarının demografik değişkenler açısından incelenmesi. Kastamonu Eğitim Dergisi. 23(1), 141-160.

Ünal, E. \& Şimşek, S. (2008). İlköğretim bölümü anabilim dallarında öğrenim gören öğretmen adaylarının mesleki benlik saygılarının çeşitli değişkenler açısından incelenmesi. ilköğretim Online. 7(1), 41-52

Vignoli, E. (2009). Inter-relationships among attachment to mother and father, self-esteem, and career indecision. Journal of Vocational Behavior. 75(2), 91-99.

Yalmancı, S. G. \& Aydın, S. (2014). Fen bilgisi öğretmen adaylarının akademik öz-yeterlik algılarının incelenmesi. Kafkas Üniversitesi, e - Kafkas Eğitim Araştırmaları Dergisi, 1(2),21-27.

Weng, Q. \& McElroy, J. C. (2010). Vocational self-concept crystallization as a mediator of the relationship between career self-management and job decision effectiveness. Journal of Vocational Behavior. 76(2), 234-243.

Yurdakul, S., Gür, B. S., Çelik, Z. \& Kurt, T. (2016). Öğretmenlik mesleği ve mesleğin statüsü. Ankara: Eğitim-Bir-Sen Stratejik Araştırmalar Merkezi. 


\section{SUMMARY}

Self concept is defined as the perception of a person of himself and refers to how one defines and evaluates himself (Kong, Ding and Zhao, 2015; Pasha and Munaf, 2013; Thomaes, Poorthuis and Nelemans, 2011). Rosenberg defines self-esteem as one's valuing, approving and appreciating himself as he is (Adler and Stewart, 2004; Negovan and Bagana, 2011). As people with high self-esteem are selfconfident and able to develop effective communication and strong relationships, they are socially adaptive as well (Gül, 2013).

Self-esteem is a tool that determines one's attitude and behaviors towards environment in both private and professional life. Self-esteem is critical in all aspects of life, including professional life (Stresemann, 2010). Job selection is one of the most important aspects that shapes a person's life and is closely ties to self-concept. Super (1963) suggested that self-concept is a predictor of one's behaviors, adding that job selection is determined by self-concept (Super, 1963; cited by Bacanli, 2003). This is because job selection is a process that requires considering one's personal characteristics. A suitable job selection and positive attitude towards this job will both make the person happy and contribute to social development (Bozdoğan, Aydın and Yıldırım, 2007).

People with higher self-esteem are more likely to enjoy doing their jobs, develop positive professional attitudes and succeed in their career. This is particularly important for teacher candidates. The more positive professional attitude and higher professional self-esteem teachers develop, the more likely they are to perform their jobs efficiently (Baloğlu, Karadağ, Çalışkan and Korkmaz, 2006).

Teacher training faculties play a key role in developing self-esteem among candidate teachers; however their student selection is just based on measurements of knowledge. Findings of this study will help to review shortcomings in education programs of these faculties and focus on the results of factors that influence self-esteem and professional self-esteem of teacher candidates from various departments.

The first step in training well-qualified teachers is to train teachers who love their jobs and have high self-esteem and professional self-esteem. This study aims to review self-esteem and professional self-esteem of teacher candidates in terms several variables including department of study, gender, age, high school, selection order of higher education and presence of a teacher in the family.

This is a relational screening study, one of the descriptive study methods. The study sample comprises 60 students from each of science education, preschool education, English language education, Turkish education, computer and instructional technologies education and music education departments from Çanakkale On Sekiz Mart University Faculty of Education, which sum up to a total of 420 students.

While collecting study data, authors used "Rosenberg Self-Esteem Scale" to measure selfesteem level of candidate teachers, "Arıcak Professional Self-Esteem Scale" to measure professional self-esteem and their own personal data form.

Evaluation of data involved both descriptive analysis and $t$ test and one-way variance analysis (ANOVA) to find out any difference between candidate teachers' self-esteem and professional selfesteem. $\alpha$ was accepted as 0.05 to determine the significance level between variables.

According to study findings, self-esteem of students at science education department is higher than students at English language education department; self-esteem is not related to variables such gender, age, high school, selection order of higher education and presence of a teacher in the family. It was found that professional self-esteem of candidates is not related to department of study, age, grade, high school and presence of a teacher in the family; however it is significantly related to gender and selection order of higher education. Study findings show that higher self-esteem is a predictor of professional self-esteem. 